\title{
The Use of Macroarray as a Simple Tool to Follow the Metabolic Profile of Lactobacillus plantarum during Fermentation
}

\author{
Minna Kahala1, Virpi Ahola², Elina Mäkimattila', Lars Paulin ${ }^{3}$, Vesa Joutsjoki ${ }^{1}$ \\ ${ }^{1}$ Biotechnology and Food Research, MTT Agrifood Research Finland, Jokioinen, Finland \\ ${ }^{2}$ Department of Biosciences, University of Helsinki, Helsinki, Finland \\ ${ }^{3}$ Institute of Biotechnology, University of Helsinki, Helsinki, Finland \\ Email: minna.kahala@mtt.fi
}

Received 25 June 2014; revised 11 July 2014; accepted 16 August 2014

Copyright @ 2014 by authors and Scientific Research Publishing Inc.

This work is licensed under the Creative Commons Attribution International License (CC BY). http://creativecommons.org/licenses/by/4.0/

(c) (i) Open Access

\section{Abstract}

This study focused on defining the differences in L. plantarum gene expression levels in different media and in different growth phases using an easy and cost-efficient monitoring of gene expression. A macroarray based on a group of selected L. plantarum genes, 178 genes belonging to 18 main groups, printed onto a nitrocellulose filter was designed in this work. Using the macrofilters designed, the expression of a selected set of $L$. plantarum genes was assayed in synthetic MRS medium and in extracted carrot juice. To compare the potential differences of starter gene expression in hygienic and contaminated cultivation media, the $L$. plantarum strain was cultivated in both sterile and contaminated (yeast and Escherichia coli) MRS and carrot juice. The number of genes found to be regulated as a function of growth was clearly higher in MRS-based growth medium than in carrot juice, In carrot juice, expression of the gene encoding malolactic enzyme (MLE), which makes L. plantarum an advantageous microbe in e.g. wine making, was found to be upregulated in logarithmic phase of growth. The current study demonstrated that macroarrays printed on nitrocellulose filters with simple robotic systems can be analyzed by standard laboratory equipment and methods usually available in molecular laboratories. Using this technology, rapid and cost-efficient analysis of genome function of $L$. plantarum can be carried out e.g. in developing regions, where lactic acid fermentation of food and feed matrices is a common practice.

\section{Keywords}

Macroarray, Gene Expression, L. plantarum

How to cite this paper: Kahala, M., Ahola, V., Mäkimattila, E., Paulin, L. and Joutsjoki, V. (2014) The Use of Macroarray as a Simple Tool to Follow the Metabolic Profile of Lactobacillus plantarum during Fermentation. Advances in Microbiology, 4, 996-1016. http://dx.doi.org/10.4236/aim.2014.414111 


\section{Introduction}

Lactic acid bacteria (LAB) are widely used for the preservation of food and feed raw materials and to intensify the flavour and texture of fermented products. Of the lactobacilli commonly used in food processes, Lactobacillus plantarum is important in the production of many fermented foods of both plant (pickled vegetables, silage, sourdough) and animal (dry ferment sausages, fermented fish, cheese) origin [1]. This versatility and ecological flexibility is most likely associated with the genome size of $L$. plantarum, which is one of the largest known among LAB [2]. Based on complete genome sequencing, $L$. plantarum has a capacity to use a large variety of carbon sources and encompasses a relatively high number of regulatory functions concentrated within a defined genomic region, which was designated the lifestyle adaptation region [3]. These genomic features exhibit an efficient adaptation capacity of $L$. plantarum to versatile environmental conditions.

Due to the ability to maintain $\mathrm{pH}$ homeostasis at low external $\mathrm{pH}, L$. plantarum is tolerant to acidic environment and often becomes the dominant $\mathrm{LAB}$ at the end of spontaneous vegetable fermentation [4]. Therefore, this species is common in vegetable and silage fermentations. Yet, spontaneous fermentation is generally poorly controlled and unstable, and the quality of products varies depending on fermented material and inherent microbiota. Spontaneously fermented vegetables may also contain among other things biogenic amines, which have been associated with certain toxicological characteristics and outbreaks of food poisoning. The formation of biogenic amines has been repressed by the use of a pure L. plantarum starter instead of spontaneous fermentation [5]. For the above reasons, well-characterized starter cultures with desirable properties would be of particular importance.

Previously, the technological properties of potential starter LAB could be determined almost exclusively in pilot- and full-scale food and feed production experiments. Today, the development of molecular techniques has made possible the exploitation of genomic and proteomic data for the observation of potential genotypic and phenotypic differences between individual strains in specific growth conditions. Studies based on L. plantarum DNA-microarrays [6], proteomic patterns [7]-[10] and sequencing technologies, like metagenomic sequencing and RNAseq [11]-[13] and transcriptional profiling [14]-[17] have been carried out to elucidate strain-specific differences in genome composition and adaptation to various growth conditions.

Both microarray and proteomic studies require specific laboratory facilities and expertise, which may not be available in all research laboratories. Yet, $L$. plantarum is used worldwide for food and feed fermentations and there is a growing demand for the design of starter cultures with well-characterized technological properties. For easy and cost-efficient monitoring of gene expression in L. plantarum, a macroarray based on a group of selected $L$. plantarum genes printed onto a nitrocellulose filter was designed in this work. Using the macrofilters designed, the expression of a selected set of L. plantarum genes was assayed in synthetic MRS medium and in extracted carrot juice. To compare the potential differences of starter gene expression in hygienic and contaminated cultivation media, the studied $L$. plantarum strain was cultivated in both sterile and contaminated (yeast and Escherichia coli) MRS and carrot juice.

\section{Materials and Methods}

\subsection{Bacterial Strains and Growth Conditions}

L. plantarum strain MLBPL1 has been isolated from sauerkraut [18] [19]. The strain was routinely grown in microaerophilic conditions at $32^{\circ} \mathrm{C}$ and maintained in MRS broth (Difco, BD, Franklin Lakes, NJ, USA). For plating, MRS was solidified with $1.5 \%$ agar. E. coli $\mathrm{DH} 5 \alpha$, carrying the plasmid vector pBluescript, was grown in Luria Bertani broth supplemented with ampicillin $(50 \mu \mathrm{g} / \mathrm{ml})$ as a selective agent at $37^{\circ} \mathrm{C} 200 \mathrm{rpm}$. For contamination cultivations, a yeast and an $E$. coli strain originating from spoiled vegetables were propagated in YGC broth at $30^{\circ} \mathrm{C}$ and in Luria Bertani broth at $37^{\circ} \mathrm{C}$, respectively.

For macroarray analyses, $L$. plantarum strain MLBPL1 was grown in synthetic medium MRS and carrot juice. To simulate contaminated growth conditions, the spoiling $E$. coli and yeast strains were inoculated into MRS and carrot juice. Cultivations were performed using Spectra/Por Float-A-Lyzer dialysis tube (MWCO 100 kDa, Spectrum Laboratories, Rancho Dominguez, CA, USA) in order to make it easier to separate the L. plantarum cells, the vegetable matrix and the spoiling strains of yeast and $E$. coli. By using the dialysis tube, no filtering of plant material was needed and in addition, the cells of contaminating strains didn't interfere with the extraction of RNA. Carrot juice was prepared from fresh vegetables with a juice extractor. The extracted juice was centrifuged at 18,500 g for $40 \mathrm{~min}$ and pasteurized in a water bath at $95^{\circ} \mathrm{C}$ for $30 \mathrm{~min}$.

An overnight culture of MLBPL1, grown in MRS-medium at $32^{\circ} \mathrm{C}$, was used to inoculate MRS broth and 
carrot juice. For MRS cultivation, a 1\% inoculumn was used. For carrot juice cultivation and contamination cultivations, the inoculumn was centrifuged at $13,000 \mathrm{~g}$ for $3 \mathrm{~min}$ and the pellet was suspended into centrifuged (18,500 g for $40 \mathrm{~min})$ and filter-sterilized (0.8/0.2 $\mu \mathrm{m}$ pore sizes) carrot juice (carrot cultivations) or MRS broth (MRS contamination cultivation), after which the suspension was transferred to a Spectra/Por Float-A-Lyzer dialysis tube. The tube was then transferred to a bottle containing carrot juice, contaminated MRS broth or contaminated carrot juice. In contamination cultivations, MRS broth and carrot juice were contaminated by inoculating them with $1 \%$ E. coli and yeast. The cultivations were performed at $32^{\circ} \mathrm{C}$. The growth was determined by plating onto MRS agar plates appropriate dilutions from the samples taken during the growth. The plates were incubated at $32^{\circ} \mathrm{C}$ for $48 \mathrm{~h}$, until single bacterial colonies appeared.

\subsection{Extraction and Labeling of RNA}

Bacterial cells of the L. plantarum strain MLBPL1 grown in MRS broth and carrot juice were harvested at exponential $(6 \mathrm{~h})$ and stationary phase $(14 \mathrm{~h})$ of growth by centrifugation for $3 \mathrm{~min}$ at $4{ }^{\circ} \mathrm{C}$ at 11,000 g. The collected cells were frozen immediately in liquid nitrogen and stored at $-70^{\circ} \mathrm{C}$. Extraction of total RNA was carried out with SV total RNA isolation system (Promega, Madison, WI, USA) with some modifications to the protocol on the disruption of the cells. Briefly, bacterial cells thawed slowly on ice were first washed with sterile water treated with diethyl pyrocarbonate (DEPC) and collected by centrifugation. Next, the pellet was resuspended into $225 \mu \mathrm{l}$ of SV RNA lysis buffer of the Promega kit and transferred to an eppendorf tube containing $100 \mu \mathrm{l}$ of nitric acid-washed glass beads. The cells were disrupted with glass beads in a cell homogenizer as described before (Kahala, et al., 2008). After that, the lysate was transferred to a new tube and $350 \mu$ lof SV RNA dilution buffer of the Promega kit was added per $175 \mu$ of lysate. From this step on, the extraction was carried on as recommended by the manufacturer. Two technical duplicates from the RNA extraction on each culture medium and harvesting point were made. mRNA was enriched from total RNA samples by removing the $16 \mathrm{~S}$ and $23 \mathrm{~S}$ rRNAs with MICROB Express Bacterial mRNA Purification kit (Ambion, Austin, TX, USA) according to the instructions of the manufacturer. The RNA concentration was determined spectrophotometrically at $260 \mathrm{~nm}$.

The integrity of the isolated prokaryotic RNA was determined by total RNA gel electrophoresis and Northern blot carried out as described by [20]. Total RNA samples, denatured with glyoxal and dimethylsulphoxide, were separated by size in a $1.0 \%(\mathrm{w} / \mathrm{v})$ agarose gel in $10 \mathrm{mM}$ sodium phosphate buffer, $\mathrm{pH} 6.5$ followed by a transfer to a positively charged nylon membrane (Roche) and hybridization with a $l d h D$-specific 736 bp probe, amplified with primer pair 5'-AAGTTAGCCGACGAAGGG-3' and 5'-CCATGTTGTGAACGGCAG-3' targeted to $L$. plantarum strain D90339.1. The probe was labelled with digoxigenin-dUTP according to the instructions of the manufacturer (Roche). Luminescent DIG detection kit (Roche) was used for hybrid detection. To detect the potential residual chromosomal DNA in the isolated mRNA sample, primers 5'-AAGTTAGCCGACGAAGGG-3' and 5'-GGGCGTATAATTCGTCCAAA-3' designed to produce a 403 bp fragment from the target $l d h D$ gene of L. plantarum strain D90339.1 were used. PCR-procedure using Dynazyme II DNA polymerase (Finnzymes, Espoo, Finland) was carried out in the reaction conditions recommended by the enzyme manufacturer.

cDNA was synthesized by RT from DNA-free mRNA and cDNA labelling was performed with an alkalilabile digoxigenin-11-dUTP (DIG) (Roche, Basel, Switzerland) in a reverse transcription reaction with Im-Prom-II Reverse Transcription System kit (Promega) as follows: $1 \mu \mathrm{g}$ of mRNA was mixed with $0.5 \mu \mathrm{g}$ of random hexamer primers provided by the kit manufacturer. The mixture was heated at $70^{\circ} \mathrm{C}$ for $5 \mathrm{~min}$ and chilled on ice for 5 min. cDNA synthesis was carried out by combining RNA-primer mixture with $1 \times$ ImProm-II reaction buffer, $5 \mathrm{mM} \mathrm{MgCl}$, $0.5 \mathrm{mM}$ dATP, $0.5 \mathrm{mM}$ dGTP, $0.5 \mathrm{mM}$ dCTP, $0.325 \mathrm{mM}$ dTTP, $0.175 \mathrm{mM}$ DIG-11dUTP, $1 \mathrm{U} / \mu \mathrm{l}$ RNasin Ribonuclease Inhibitor, and $1 \mu \mathrm{l}$ ImProm-II Reverse Transcriptase. Annealing was performed at $25^{\circ} \mathrm{C}$ for $5 \mathrm{~min}$, followed by extension at $43^{\circ} \mathrm{C}$ for $1 \mathrm{~h}$ and enzyme inactivation at $70^{\circ} \mathrm{C}$ for $15 \mathrm{~min}$. The labeled cDNA was purified with Microarray Target Purification kit (Roche) according to the instructions of the manufacturer.

\subsection{PCR and Labeling of the Positive Control for Macroarray}

Human-based HbGAM (heparin-binding growth-associated molecule) gene [21] inserted into the plasmid pBluescript (Agilent Technologies, Santa Clara, CA) was amplified with polymerase chain reaction (PCR) to be used as a positive control in macroarray analyses. PCR reactions were carried out with Dynazyme II DNA polymerase (Finnzymes, Espoo, Finland) using the reaction conditions recommended by the manufacturer. Bacte- 
rial lysate of the E. coli strain DH5 $\alpha$, harbouring the recombinant pBluescript-HbGAM plasmid to be used as a template for PCR, was obtained by disrupting the cells with glass beads. To amplify the HbGAM gene, the primer pair 5'-GTAAAACGACGGCCAG-3' and 5'-CAGGAAACAGCTATGAC-3' targeting the plasmid was used. The amplified PCR product was purified with Wizard ${ }^{\circledR}$ SV Gel and PCR Clean-Up System (Promega) and labelled with DIG-11-dUTP using DIG-High Prime labeling kit (Roche).

\subsection{Amplification of L. plantarum MLBPL1 Genes and Macroarray Printing}

Primers were designed for the amplification of selected genes from the fully sequenced genome of $L$. plantarum WCFS1 [3]. The gene list and designed primers are listed in Supplement 1. To enable an easy re-amplification of the PCR-products, universal nucleotide sequences were added to the 5' termini of the specific forward and reverse primers. A nucleotide sequence 5' CCGCTGCTAGGCGCGCCGTG was added to the forward primers and, respectively, a nucleotide sequence 5' GCAGGGATGCGGCCGCTGAC was added to the reverse primers. Amplification of the selected genes was done as described for the positive control for macroarray. For the PCR reaction, a 10 pmol primer concentration and $20 \mathrm{ng}$ of corresponding genomic template DNA were used in a 100 $\mu \mathrm{l}$ reaction volume in a 96 well PCR plate. The success of the PCR amplification was checked by analyzing $5 \mu \mathrm{l}$ from the reactions on a $1 \%$ agarose gel. The obtained PCR products were purified using Montage PCR Purification 96 Well Plates (Millipore).

PCR fragments in the 96 well plates were transferred to 384 plates for printing on the nitrocellulose macroarray (Supplement 2). Purified PCR fragments were gridded in duplicate on nitrocellulose membranes with a QPix automated colony picker (Genetix Ltd., UK) using a 384-pin gridding head as described in [22].

\subsection{Hybridization and Detection}

Macroarrays were prehybridized for $2 \mathrm{~h}$ at $60^{\circ} \mathrm{C}$ with $20 \mathrm{ml}$ of DIG Easy Hyb buffer (Roche). Hybridizations were performed overnight at $60^{\circ} \mathrm{C}$ with $6 \mathrm{ml}$ DIG Easy Hyb buffer (Roche) containing $5 \mu \mathrm{l}$ of labeled cDNA probe and HbGAM which was used as a positive control in hybridization reactions. After hybridization, macroarrays were washed twice at room temperature for 5 min with washing solution containing $2 \times$ SSC $(1 \times$ SSC is $0.15 \mathrm{M} \mathrm{NaCl}$ and $15 \mathrm{mM}$ sodium citrate) and $0.1 \%$ sodium dodecyl sulphate (SDS) and twice at $68^{\circ} \mathrm{C}$ for 15 min with washing solution $(0.1 \times$ SSC, $0.1 \%$ SDS). Hybridized spots were detected with chemiluminesence-based DIG detection kit (Roche) using CDP-Star (Roche) as a substrate and chemiluminescence produced was detected by FluorChem (Alpha Innotech Corp., San Leandro, CA) gel image system. For reprobing, the DIG-labelled probe was removed with a following procedure. The membrane was rinsed thoroughly in sterile water, washed twice with $0.2 \mathrm{M} \mathrm{NaOH}$ containing $0.1 \% \mathrm{SDS}$ at $37^{\circ} \mathrm{C}$ for $20 \mathrm{~min}$ and rinsed with $2 \times$ SSC for 5 min.

\subsection{Statistical Methods}

The DNA probes spotted on the macroarray were selected using results from the previous proteomics results using 2-DE and HPLC-ESI-MS/MS [8]. Additionally, computationally predicted expression values were used for choosing the remaining probes. Codon usage differences (codon bias) were used for predicting gene expression levels for all 3009 genes of L. plantarum (C) [3], and the set of 63 genes encoding ribosomal proteins (RB). Codon bias for a gene $g$ with respect to gene set $G$ was calculated by the formula

$$
B(g \mid G)=\sum_{a} p a(g)\left[\sum_{(x, y, z)=a}|f(x, y, z)-g(x, y, z)|\right]
$$

where $f(x, y, z)$ denotes a normalized frequency of the codon triplet $(x, y, z)$ coding for an amino acid $a$ in a gene $g$, $g(x, y, z)$ denotes the frequency of the codon triplet $(x, y, z)$ in the gene set $G$, and $p_{a}(g)$ is the fraction of the amino acid $a$ in the gene $g$ [23].

The gene $g$ was predicted as highly expressed if the relative codon bias

$$
R C B=\frac{B(g \mid C)}{B(g \mid R B)}
$$

exceeded 1.05. The genes obtaining the greatest $R C B$ values were chosen for the DNA macroarray filter in addi- 
tion to those identified by the HPLC-ESI-MS/MS.

After scanning of the macroarray images, the quantification of the hybridized signals and background subtraction were done by the TIGR Spotfinder image processing software [24]. After quantification and background correction, the signals were normalized using median array intensities. Finally, the expression levels for each gene and sample was obtained by taking median of the normalized intensity values across the two replicates of each sample. Gene expression levels were compared between MRS, carrot juice and contaminated versions of the growth media in exponential $(6 \mathrm{~h})$ and stationary $(14 \mathrm{~h})$ growth phases. The pair-wise comparisons were made using fold changes, ratios of the mean expression levels. Fold changes greater than two are reported in the results. All genes in the array were grouped into functional groups according to their main roles. Gene set enrichment analysis was made for the gene sets with fold change greater than two in order to test whether any functional group is overrepresented among the differentially expressed genes between two growth media. Analyses were made using SAS $^{\circledR}$ (SAS for Windows 9.1).

\section{Results}

Growth rate of $L$. plantarum MLBPL1 cells was similar in MRS and carrot juice (Figure 1). Integrity and purity of the isolated RNA were demonstrated by Northern blot and PCR of the $l d h D$ gene (data not shown).

The macroarray included 178 genes belonging to 18 main groups. The largest groups were energy metabolism (59 genes), protein synthesis (30 genes), protein fate (10 genes), regulatory functions (10 genes), cell envelope (9 genes) and DNA metabolism (9 genes). Of the 178 genes tested, 18 (10\%) showed a mean fold change greater than 2.0 in at least one of the ten comparisons between growth media or growth phases (Table 1). The most frequent functions included were energy metabolism, cell envelope, protein fate and nucleotide metabolism.

\subsection{Expression Levels of the Genes as a Function of Growth}

The majority of the genes studied on the membranes showed no significant change in levels of expression during the growth or between the growth media. The number of the genes found to be regulated as a function of growth was clearly higher in MRS-based growth medium than in carrot juice, in which only genes involved in fatty acid and phospholipid metabolism showed differential expression in different growth phases. The function of the genes showing upregulation in logarithmic phase in MRS medium was mostly related to energy metabolism, but also to cell division, cell envelope biosynthesis and pyrimidine ribonucleotide biosynthesis. Generation of sufficient energy for growth in logarithmic phase is important and was evidenced in the MRS based medium.

In MRS cultivation, when entering in the stationary phase of growth, transcription of genes involved in energy metabolic pathways decreased and higher expression levels were found for genes involved in protein fate, protein folding and stabilization, like "folding” chaperones DnaK and GroEL. In contaminated MRS medium, especially the expression levels of genes involved in sugar metabolism pathways ( $g a l K, l a c M$ ) were found to be higher in logarithmic phase. This reflects higher demand for energy in the logarithmic phase and probably competition between the Lactobacillus and contaminating strains in the utilization of sugars that are needed for growth.

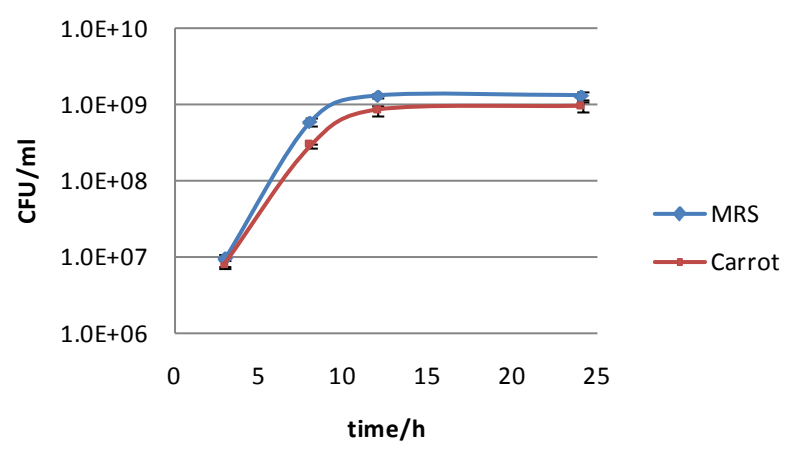

Figure 1. Growth of L. plantarum MLBPL1 in two growth media. 
Table 1. Genes and their main roles showing mean fold change $>2.0$ in ten comparisons among growth media and two growth phases. Minus and plus signs show which of the compared groups has higher expression: +: shows higher expression in the first; -: in the second group.

\begin{tabular}{|c|c|c|c|c|c|c|c|c|c|c|c|c|}
\hline 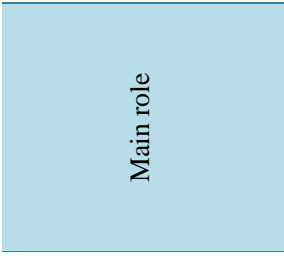 & 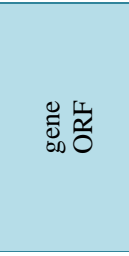 & 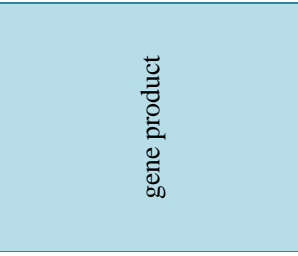 & 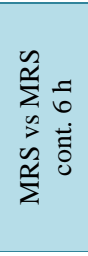 & 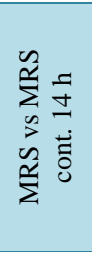 & 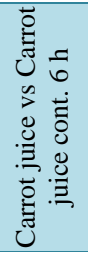 & 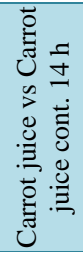 & 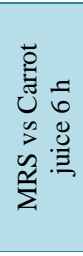 & 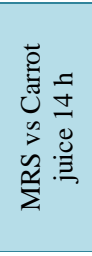 & $\begin{array}{l} \pm \\
\pm \\
n \\
z \\
\frac{\Xi}{0} \\
0 \\
\tilde{z}\end{array}$ & 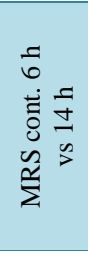 & 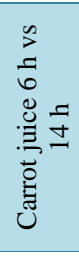 & 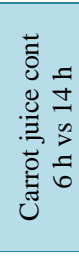 \\
\hline $\begin{array}{l}\text { Energy metabolism- } \\
\text { Pyruvate dehydrogenase }\end{array}$ & $\begin{array}{l}\text { pdhB } \\
\text { lp_2153 }\end{array}$ & $\begin{array}{l}\text { pyruvate dehydrogenase } \\
\text { complex, E1 component, } \\
\text { beta subunit }\end{array}$ & -2.20 & - & - & - & - & - & - & - & - & - \\
\hline \multirow[t]{2}{*}{$\begin{array}{c}\text { Energy metabolism- } \\
\text { Sugars }\end{array}$} & $\begin{array}{l}\text { galK } \\
\text { lp_3482 }\end{array}$ & galactokinase & -3.01 & - & - & - & - & - & - & +2.13 & - & - \\
\hline & $\begin{array}{c}\text { lacM } \\
\text { lp_3484 }\end{array}$ & $\begin{array}{l}\text { beta-galactosidase, } \\
\text { small subunit }\end{array}$ & -2.30 & - & - & - & - & - & - & +2.43 & - & - \\
\hline $\begin{array}{c}\text { Energy metabolism- } \\
\text { Glycolysis/ } \\
\text { gluconeogenesis }\end{array}$ & $\begin{array}{c}\text { pyk } \\
\text { lp_1897 }\end{array}$ & pyruvate kinase & - & - & - & - & - & -2.32 & - & - & - & - \\
\hline $\begin{array}{c}\text { Energy metabolism- } \\
\text { Pentose phosphate } \\
\text { pathway }\end{array}$ & $\begin{array}{l}\text { rpiA1 } \\
\text { lp_0602 }\end{array}$ & $\begin{array}{c}\text { ribose } 5 \text {-phosphate } \\
\text { epimerase }\end{array}$ & - & - & - & - & - & - & +2.02 & - & - & - \\
\hline $\begin{array}{l}\text { DNA metabolism- } \\
\text { DNA replication, } \\
\text { recombination }\end{array}$ & $\begin{array}{c}\text { dnaN } \\
\text { lp_0002 }\end{array}$ & $\begin{array}{l}\text { DNA-directed DNA } \\
\text { polymerase III, beta } \\
\text { chain }\end{array}$ & - & - & - & - & - & - & - & - & - & +2.15 \\
\hline $\begin{array}{l}\text { Cellular processes- } \\
\text { Cell division }\end{array}$ & $\begin{array}{c}\text { ftsH } \\
\text { lp_0547 }\end{array}$ & $\begin{array}{l}\text { cell division protein } \\
\text { FtsH, ATP-dependent } \\
\text { zinc metallopeptidase }\end{array}$ & - & -2.06 & - & - & - & - & +2.28 & - & - & - \\
\hline $\begin{array}{l}\text { Cell envelope- } \\
\text { Biosynthesis and } \\
\text { degradation }\end{array}$ & lp_0304 & extracellular protein & - & - & - & - & - & - & +2.16 & - & - & - \\
\hline Cell envelope-Other & lp_2290 & $\begin{array}{c}\text { integral membrane } \\
\text { protein }\end{array}$ & - & - & - & - & - & - & +2.41 & - & - & - \\
\hline $\begin{array}{c}\text { Signal transduction- } \\
\text { PTS }\end{array}$ & $\begin{array}{l}\text { pts16ABC } \\
\text { lp_2097 }\end{array}$ & fructose PTS, EIIABC & - & -2.50 & - & - & - & -2.86 & - & - & - & - \\
\hline $\begin{array}{l}\text { Enzymes of unknown } \\
\text { specificity }\end{array}$ & $\begin{array}{c}\text { mleS } \\
\text { lp_1118 }\end{array}$ & malolactic enzyme & - & - & +2.32 & +2.17 & -2.56 & -2.28 & - & - & - & - \\
\hline $\begin{array}{l}\text { Fatty acid and } \\
\text { phospholipid } \\
\text { metabolism- } \\
\text { Biosynthesis }\end{array}$ & $\begin{array}{c}\text { fabF } \\
\text { lp_1675 }\end{array}$ & $\begin{array}{l}\text { 3-oxoacyl-[acyl-carrier } \\
\text { protein] synthase II }\end{array}$ & - & - & - & - & - & - & - & - & +2.18 & \\
\hline $\begin{array}{c}\text { Purines, pyrimidines, } \\
\text { nucleosides, and } \\
\text { nucleotides- }\end{array}$ & $\begin{array}{l}\text { pyrD, } \\
\text { lp_2697 }\end{array}$ & dihydroorotate oxidase, & - & - & - & - & +3.74 & - & - & +2.02 & - & - \\
\hline $\begin{array}{l}\text { Pyrimidine } \\
\text { ribonucleotide } \\
\text { biosynthesis }\end{array}$ & $\begin{array}{l}\text { pyrC, } \\
\text { lp_2699 }\end{array}$ & dihydroorotase & - & - & - & - & +3.36 & - & +2.54 & - & - & - \\
\hline $\begin{array}{l}\text { Transport and binding } \\
\text { proteins-Amino acids, } \\
\text { peptides }\end{array}$ & $\begin{array}{c}\text { oppA } \\
\text { lp_1261 }\end{array}$ & $\begin{array}{l}\text { oligopeptide ABC } \\
\text { transporter, substrate } \\
\text { binding protein }\end{array}$ & - & - & - & - & -2.41 & - & - & - & - & - \\
\hline \multirow{3}{*}{$\begin{array}{l}\text { Protein fate-- } \\
\text { Protein folding and } \\
\text { stabilization }\end{array}$} & $\begin{array}{l}\text { groEL } \\
\text { lp_0728 }\end{array}$ & GroEL chaperonin & - & - & - & - & - & - & -2.25 & - & - & - \\
\hline & $\begin{array}{c}\text { dnaK } \\
\text { lp_2027 }\end{array}$ & $\begin{array}{c}\text { heat shock protein DnaK } \\
\text { GTP-binding protein }\end{array}$ & - & - & - & - & - & - & -2.17 & - & - & - \\
\hline & $\begin{array}{c}\text { typA } \\
\text { lp_2146 }\end{array}$ & ТурА & - & - & - & - & - & - & +2.45 & - & - & - \\
\hline Unknown function & lp_3092 & $\begin{array}{c}\text { fumarate reductase, } \\
\text { flavoprotein subunit } \\
\text { precursor, N-terminally } \\
\text { truncated }\end{array}$ & - & - & - & - & - & - & -2.13 & - & - & - \\
\hline
\end{tabular}




\subsection{Expression Levels of the Genes between Different Growth Media}

The mRNA level of several genes was shown to be regulated in response to different growth media. At the exponential $(6 \mathrm{~h})$ phase of growth, the genes encoding dihydroorotate oxidase and dihydroorotase enzymes were differentially expressed in MRS and carrot juice. They showed 3.7- and 3.4-fold higher expression in the MRS compared to carrot juice growth medium, respectively (Table 1). Differential expression $(p=0.015)$ of these genes encoding proteins involved in pyrimidine ribonucleotide biosynthesis is an indication of distinct gene regulation and, consequently, potentially different rate of pyrimidine biosynthesis in synthetic MRS compared to vegetable-based carrot juice cultivation medium.

Expression of malolactic enzyme (mle) gene was clearly higher in logarithmic phase when grown in plant based medium. Upregulation of cell division protein FtsH was observed in contaminated MRS $14 \mathrm{~h}$ compared to MRS $14 \mathrm{~h}$, probably indicating higher stress response in contaminated MRS.

\section{Discussion}

This study focused on defining the differences in L. plantarum gene expression levels in different media and in different growth phases by the use of a simple and low-cost macroarray technique. Previously described DNA macroarray technique [22] has been further developed for studying gene expression profile of the industrially important lactic acid bacterium.

Fermentation conditions may dramatically affect functional characteristics of LAB [13]. Marked changes in expression levels upon entry in the stationary phase have been found out [25] [26]. Highly expressed genes are turned off or markedly repressed and genes, mostly inactive in the growing cells, begin to be expressed in the stationary phase [25] [26]. In this study, transcription of genes involved in energy metabolic pathways decreased in stationary phase and higher expression levels were found for genes like "folding" chaperones DnaK and GroEL. GroEL basal expression is enhanced by environmental stress, including elevated temperature, oxygen limitation, and nutrient deprivation [27] [28]. DnaK plays a central role in protein folding, refolding, translocation and in the stress conditions. The elevated expression of these genes is probably a response to the diminishing nutrients and high concentration of lactic acid in the medium which is known to cause stress especially in the late-stationary phase [29].

Proteomic studies by [10] has revealed significant changes on fermentation profiles of L. plantarum strains previously grown under food-like conditions compared to cultivation in MRS broth. In our study, expression of a malolactic enzyme (mle) gene in plant-based medium was found to be upregulated in logarithmic phase of growth. Mle enzymes, involved in decarboxylation of L-malic acid to L-lactic acid and $\mathrm{CO}_{2}$ [30], have been purified from several lactic acid bacteria, including Leuconostoc mesenteroides, L. plantarum, and Leuconostoc oenos [31]. In several studies, L. plantarum has been shown to have malolactic activity and therefore is of interest in wine production [32]. The significance of malolactic activity of LAB in sauerkraut fermentation has also been reported. Conversion of malic acid into lactic acid before significant sugar metabolism may play some role in early fermentation [30] [33].

Higher expression of cell division protein FtsH in contaminated MRS compared to MRS probably indicated higher stress response in contaminated MRS. Functional studies have revealed an important role for FtsH in the bacterial stress response. In several bacteria, including E. coli, B. subtilis, Lactococcus lactis, O. oeni, Helicobacter pylori, and L. plantarum, fts $H$ expression is induced in response to heat and other stress factors controlled by additional regulators [34].

Macroarray was found to be an applicable method for studying expression of defined genes of L. plantarum during fermentation. Macroarray technology has been successfully applied also e.g. for the detection of pathogens in chicken samples [35] and studies on environmental samples for the presence of specific antibiotic resistance genes [36] communities of diazotrophs [37], and expression of 375 genes in L. lactis subsp. lactis IL1403 during stress conditions [38].

L. plantarum is encountered in a variety of environmental niches, which include dairy, meat and many vegetable or plant fermentations as well as the human gastrointestinal tract. Because of this flexibility and versatility, strains of this species have been traditionally used for food and feed preservation and as starters in the manufacture of fermented products. Formerly, the technological properties and suitability of certain strains to selected applications could be ensured almost exclusively by laborious and time-consuming food processing and preservation experiments. Today, the long history of use and on the other hand the development of molecular and ge- 
nomic techniques have made L. plantarum one of the most studies food microbes. Modern DNA microarray [6], next-generation sequencing technologies [39] and especially transcriptomic studies are accurate and sensitive and have enabled the detailed examination of $L$. plantarum genome structure and function. The most advanced technologies, however, require specific instrumentation and have often high running costs, which may rule out their use in many cases. The current study demonstrated that macroarrays printed on nitrocellulose filters with simple robotic systems can be analyzed by standard laboratory equipment and methods usually available in molecular laboratories. Using this technology, rapid and cost-efficient analysis of genome function of $L$. plantarum can be carried out e.g. in developing regions, where lactic acid fermentation of food an feed matrices is a common practice, but research and analysis laboratories often lack the most expensive specific laboratory instrumentation.

\section{Acknowledgements}

Tekes, the Finnish Funding Agency for Technology and Innovation, is gratefully acknowledged for the financial support of this work. The authors wish to thank Anneli Paloposki for the skilful technical assistance, Ari-Matti Sarén for designing the primers, Markku Ala-Pantti and Hannu Väänänen for printing the membranes.

\section{References}

[1] Rose, A. (1982) History and Scientific Basis of Microbial Activity in Fermented Foods. In: Rose, A., Ed., Fermented Foods, Academic Press, New York, 1-13.

[2] Chevallier, B., Hubert, J.C. and Kammerer, B. (1994) Determination of Chromosome Size and Number of rrn Loci in Lactobacillus plantarum by Pulsed-Field Gel Electrophoresis. FEMS Microbiology Letters, 120, 51-56. http://dx.doi.org/doi:10.1111/j.1574-6968.1994.tb07006.x

[3] Kleerebezem, M., Boekhorst, J., van Kranenburg, R., Molenaar, D., Kuipers, O.P., Leer, R., Tarchini, R., Peters, S.A., Sandbrink H.M., Fiers, M., Stiekema, W., Lankhorst, R., Bron, P., Hoffer, S., Groot, M., Kerkhoven, R., de Vries, M., Ursing, B., de Vos, W.M. and Siezen, R.J. (2003) Complete Genome Sequence of Lactobacillus plantarum WCFS1. Proceedings of the National Academy of Sciences of the United States of America, 100, 1990-1995. http://dx.doi.org/10.1073/pnas.0337704100

[4] McDonald, L.C., Fleming, H.P. and Hassan, H.M. (1990) Acid Tolerance of Leuconostoc mesenteroides and Lactobacillus plantarum. Applied and Environmental Microbiology, 56, 2120-2124.

[5] Mäki, M. (2004) Lactic Acid Bacteria in Vegetable Fermentations. In: Salminen, S., von Wright, A. and Ouwehand, A., Eds., Lactic Acid Bacteria: Microbiological and Functional Aspects, 2nd Edition, Marcel Dekker, Inc., New York, 419-430. http://dx.doi.org/10.1201/9780824752033.ch14

[6] Molenaar, D., Bringel, F., Schuren, F.H., De Vos, W.M., Siezen, R.J. and Kleerebezem, M. (2005) Exploring Lactobacillus plantarum Genome Diversity by Using Microarrays. Journal of Bacteriology, 187, 6119-6127.

[7] Koistinen, K.M., Plumed-Ferrer, C., Lehesranta, S.J., Kärenlampi, S.O. and von Wright, A. (2007) Comparison of Growth-Phase-Dependent Cytosolic Proteomes of Two Lactobacillus plantarum Strains Used in Food and Feed Fermentations. FEMS Microbiology Letters, 273, 12-21. http://dx.doi.org/10.1111/j.1574-6968.2007.00775.X

[8] Plumed-Ferrer, C., Koistinen, K.M., Tolonen, T.L., Lehesranta, S.J., Kärenlampi, S.O., Mäkimattila, E., Joutsjoki, V., Virtanen, V. and von Wright, A. (2008) Comparative Study of Sugar Fermentation and Protein Expression Patterns of Two Lactobacillus plantarum Strains Grown in Three Different Media. Applied and Environmental Microbiology, 74, 5349-5358. http://dx.doi.org/10.1128/AEM.00324-08

[9] Di Cagno, R., Surico, R.F., Siragusa, S., De Angelis, M., Paradiso, A., Minervini, F., De Gara, L. and Gobbetti, M. (2008) Selection and Use of Autochthonous Mixed Starter for Lactic Acid Fermentation of Carrots, French Beans or Marrows. International Journal of Food Microbiology, 127, 220-228. http://dx.doi.org/10.1016/j.ijfoodmicro.2008.07.010

[10] Siragusa, S., De Angelis, M., Calasso, M., Campanella, D., Minervini, F., Di Cagno, R. and Gobbetti, M. (2013) Fermentation and Proteome Profiles of Lactobacillus plantarum Strains during Growth under Food-Like Conditions. Journal of Proteomics, 96, 366-380. http://dx.doi.org/10.1016/j.jprot.2013.11.003

[11] Stevens, M.J.A., Wiersma, A., de Vos, W.M., Kuipers, O.P., Smid, E.J., Molenaar, D. and Kleerebezem, M. (2008) Improvement of Lactobacillus plantarum Aerobic Growth as Directed by Comprehensive Transcriptome Analysis. Applied and Environmental Microbiology, 74, 4776-4778. http://dx.doi.org/10.1128/AEM.00136-08

[12] Wels, M., Overmars, L., Francke, C., Kleerebezem, M. and Siezen, R.J. (2011) Reconstruction of the Regulatory Network of Lactobacillus plantarum WCFS1 on Basis of Correlated Gene Expression and Conserved Regulatory Motifs. 
Microbial Biotechnology, 4, 333-344. http://dx.doi.org/10.1111/j.1751-7915.2010.00217.x

[13] Bron, P.A., Wels, M., Bongers, R.S., de Veen, H., Wiersma, A., Overmars, L., Marco, M.L. and Kleerebezem, M. (2012) Transcriptomes Reveal Genetic Signatures Underlying Physiological Variations Imposed by Different Fermentation Conditions in Lactobacillus plantarum. PloS ONE, 7, e38720. http://dx.doi.org/10.1371/journal.pone.0038720

[14] Reverón, I., Rivas, B., Muñoz, R. and de Felipe, F.L. (2012) Genome-Wide Transcriptomic Responses of a Human Isolate of Lactobacillus plantarum Exposed to p-Coumaric Acid Stress. Molecular Nutrition \& Food Research, 56, 18481859. http://dx.doi.org/10.1002/mnfr.201200384

[15] Todt, T.J., Wels, M., Bongers, R.S., Siezen, R.S., van Hijum, S.A.F.T. and Kleerebezem, M. (2012) Genome-Wide Prediction and Validation of Sigma70 Promoters in Lactobacillus plantarum WCFS1. PloS ONE, 7, e45097. http://dx.doi.org/10.1371/journal.pone.0045097

[16] de Veen, H., Abee, T., Tempelaars, M., Bron, P.A., Kleerebezem, M. and Marco, M.L. (2011) Short- and Long-Term Adaptation to Ethanol Stress and Its Cross-Protective Consequences in Lactobacillus plantarum. Applied and Environmental Microbiology, 77, 5247-5256. http://dx.doi.org/10.1128/AEM.00515-11

[17] Wegkamp, A., Mars, A.E., Faijes, M., Molenaar, D., de Vos, R.C.H., Klaus, S.M.J., Hanson, A.D., de Vos, W.M. and Smid, E.J. (2010) Physiological Responses to Folate Overproduction in Lactobacillus plantarum WCFS1. Microbial Cell Factories, 9, 100. http://dx.doi.org/10.1186/1475-2859-9-100

[18] Tamminen, M., Mäki, M. and Joutsjoki, T. (2003) Differentiation of Lactobacilli Related to Lactobacillus plantarum from Naturally Fermented Cucumbers and White Cabbage. Applied Biotechnology, Food Science and Policy, 1, 125128.

[19] Tamminen, M., Joutsjoki, T., Sjöblom, M., Joutsen, M., Palva, A., Ryhänen, E.L. and Joutsjoki, V. (2004) Screening of Lactic Acid Bacteria from Fermented Vegetables by Carbohydrate Profiling and PCR-ELISA. Letters in Applied Microbiology, 39, 439-444. http://dx.doi.org/10.1111/j.1472-765X.2004.01607.x

[20] Hames, B. and Higgins, S. (1985) Nucleic Acid Hybridization: A Practical Approach. IRL Press, Oxford.

[21] Raulo, E., Chernousov, M.A., Carey, D.J., Nolo, R. and Rauvala, H. (1994) Isolation of a Neuronal Cell Surface Receptor of Heparin Binding Growth-Associated Molecule (HB-GAM). Identification as N-Syndecan (Syndecan-3). The Journal of Biological Chemistry, 269, 12999-13004.

[22] Hultman, J., Pitkäranta, M., Romantschuk, M., Auvinen, P. and Paulin, L. (2008) Probe-Based Negative Selection for Underrepresented Phylotypes in Large Environmental Clone Libraries. Journal of Microbiological Methods, 75, 457463. http://dx.doi.org/10.1016/j.mimet.2008.07.016

[23] Karlin, S. and Mrázek, J. (2000) Predicted Highly Expressed Genes of Diverse Prokaryotic Genomes. Journal of Bacteriology, 182, 5238-5250. http://dx.doi.org/10.1128/JB.182.18.5238-5250.2000

[24] Saeed, A.I., Sharov, V., White, J., Li, J., Liang, W., Bhagabati, N., Braisted, J., Klapa, M., Currier, T., Thiagarajan, M., Sturn, A., Snuffin, M., Rezantsev, A., Popov, D., Ryltsov, A., Kostukovich, E., Borisovsky, I., Liu, Z., Vinsavich, A., Trush, V. and Quackenbush, J. (2003) TM4: A Free, Open-Source System for Microarray Data Management and Analysis. BioTechniques, 34, 374-378. http://dx.doi.rg/12613259

[25] Ishihama, A. (1997) Adaptation of Gene Expression in Stationary Phase Bacteria. Current Opinion in Genetics and Development, 7, 582-588. http://dx.doi.org/10.1016/S0959-437X(97)80003-2

[26] Ishihama, A. (1999) Modulation of the Nucleoid, the Transcription Apparatus, and the Translation Machinery in Bacteria for Stationary Phase Survival. Genes to Cells, 4, 135-143. http://dx.doi.org/10.1046/j.1365-2443.1999.00247.x

[27] Bergonzelli, G.E., Granato, D., Pridmore, R.D., Marvin-Guy, L.F., Donnicola, D. and Corthésy-Theulaz, I.E. (2006) GroEL of Lactobacillus johnsonii La1 (NCC 533) Is Cell Surface Associated: Potential Role in Interactions with the Host and the Gastric Pathogen Helicobacter pylori. Infection and Immunity, 74, 425-434. http://dx.doi.org/10.1128/IAI.74.1.425-434.2006

[28] Lamberti, C., Mangiapane, E., Pessione, A., Mazzoli, R., Giunta, C. and Pessione, E. (2011) Proteomic Characterization of a Selenium-Metabolizing Probiotic Lactobacillus reuteri Lb2 BM for Nutraceutical Applications. Proteomics, 11, 2212-2221. http://dx.doi.org/10.1002/pmic.201000747

[29] Cohen, D.P.A., Renes, J., Bouwman, F.G., Zoetendal, E.G., Mariman, E., de Vos, W.M. and Vaughan, E.E. (2006) Proteomic Analysis of Log to Stationary Growth Phase Lactobacillus plantarum Cells and a 2-DE Database. Proteomics, 6, 6485-6493. http://dx.doi.org/10.1002/pmic.200600361

[30] Johanningsmeier, S.D., Fleming, H.P. and Breidt Jr., F. (2004) Malolactic Activity of Lactic Acid Bacteria during Sauerkraut Fermentation. Journal of Food Science, 69, M222-M227. http://dx.doi.org/10.1111/j.1365-2621.2004.tb09891.x

[31] Labarre, C., Guzzo, J., Cavin, J.F., Diviès, C., Labarre, C. and Guzzo, J. (1996) Cloning and Characterization of the Genes Encoding the Malolactic Enzyme and the Malate Permease of Leuconostoc oenos. Applied and Environmental Microbiology, 62, 1274-1282. 
[32] G-Alegría, E., López, I., Ruiz, J.I., Sáenz, J., Fernández, E., Zarazaga, M., Dizy, M., Torres, C. and Ruiz-Larrea, F. (2004) High Tolerance of Wild Lactobacillus plantarum and Oenococcus oeni Strains to Lyophilisation and Stress Environmental Conditions of Acid $\mathrm{pH}$ and Ethanol. FEMS Microbiology Letters, 230, 53-61. http://dx.doi.org/10.1016/S0378-1097(03)00854-1

[33] Johanningsmeier, S.D. and McFeeters, R.F. (2013) Metabolism of Lactic Acid in Fermented Cucumbers by Lactobacillus buchneri and Related Species, Potential Spoilage Organisms in Reduced Salt Fermentations. Food Microbiology, 35, 129-135. http://dx.doi.org/10.1016/j.fm.2013.03.004

[34] Fiocco, D., Crisetti, E., Capozzi, V. and Spano, G. (2007) Validation of an Internal Control Gene to Apply Reverse Transcription Quantitative PCR to Study Heat, Cold and Ethanol Stresses in Lactobacillus plantarum. World Journal of Microbiology and Biotechnology, 24, 899-902. http://dx.doi.org/10.1007/s11274-007-9556-7

[35] Kupradit, C., Rodtong, S. and Ketudat-Cairns, M. (2013) Development of a DNA Macroarray for Simultaneous Detection of Multiple Foodborne Pathogenic Bacteria in Fresh Chicken Meat. World Journal of Microbiology \& Biotechnology, 29, 2281-2291. http://dx.doi.org/10.1007/s11274-013-1394-1

[36] Patterson, A.J., Colangeli, R., Spigaglia, P. and Scott, K.P. (2007) Distribution of Specific Tetracycline and Erythromycin Resistance Genes in Environmental Samples Assessed by Macroarray Detection. Environmental Microbiology, 9, 703-715. http://dx.doi.org/10.1111/j.1462-2920.2006.01190.x

[37] Jenkins, B.D., Steward, G.F., Short, S.M., Ward, B.B. and Zehr, J.P. (2004) Fingerprinting Diazotroph Communities in the Chesapeake Bay by Using a DNA Macroarray. Applied and Environmental Microbiology, 70, 1767-1776. http://dx.doi.org/10.1128/AEM.70.3.1767-1776.2004

[38] Xie, Y., Chou, L., Cutler, A. and Weimer, B. (2004) DNA Macroarray Profiling of Lactococcus lactis subsp. lactis IL1403 Gene Expression during Environmental Stresses. Applied and Environmental Microbiology, 70, 6738-6747. http://dx.doi.org/10.1128/AEM.70.11.6738

[39] Leimena, M.M., Wels, M., Bongers, R.S., Smid, E.J., Zoetendal, E.G. and Kleerebezem, M. (2012) Comparative Analysis of Lactobacillus plantarum WCFS1 Transcriptomes by Using DNA Microarray and Next-Generation Sequencing Technologies. Applied and Environmental Microbiology, 78, 4141-4148. http://dx.doi.org/10.1128/AEM.00470-12 
Supplement 1. Primers designed for PCR amplification of the selected genes.

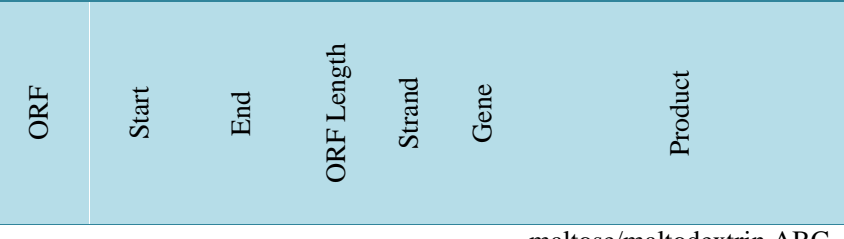

maltose/maltodextrin ABC P_0175 $151222152475-$ malE $\begin{gathered}\text { transporter, } \\ \text { substrate binding protein }\end{gathered}$

lp_0230 $2089132107511839+$ pts2CB mannitol PTS, EIICB

lp_0233 $2133292144861158+$ mtlD mannitol-1-phosphate

5-dehydrogenase

lp_0257 $232292233083792 \quad$ - pepM methionyl aminopeptidase

lp_0302 $278235279038 \quad 804 \quad$ - $\quad$ extracellular protein

lp_0304 $280089280727 \quad 639 \quad$ - $\quad$ extracellular protein

lp_0330 $301990302853864+$ fba fructose-bisphosphate

lp_0447 $4015884028621275+$ mvaA hydroxymethylglutarylCoA reductase

lp_0480 $428432429031600+$ rpoE $\begin{gathered}\text { DNA-directed RNA } \\ \text { polymerase, delta subunit }\end{gathered}$

lp_0537 $485467486429963 \quad$ - $\quad$ ldhL1 L-lactate dehydrogenase

lp_0539487338490865 $3528+\operatorname{mfd}$ transcription-repair coupling factor

cell division protein FtsH,

lp_0547 $4963824986192238+$ ftsH $\quad \begin{gathered}\text { ATP-dependent zinc } \\ \text { AT }\end{gathered}$ metallopeptidase

lp_0576 $534155534961807+$ pts9C mannose PTS, EIIC

lp_0577 $534979535896918+$ pts9D mannose PTS, EIID

lp_0601 5726905740211332 - pepC1 cysteine aminopeptidase

lp_0609579545 $5810351491+$ gltX glutamate--tRNA ligase

lp_0619587629 $588054426+$ rplK $\quad$ ribosomal protein L11

lp_0620 $588155588844690+$ rplA $\quad$ ribosomal protein L1

lp_0621 $589043589546504 \quad+\quad$ rplJ $\quad$ ribosomal protein L10

lp_0690634153636711 $2559+\quad$ integral membrane protein (putative)

ribonucleosidelp_0692 $6375436385531011 \quad-\quad$ nrdF $\begin{gathered}\text { ribonucleoside- } \\ \text { diphosphate reductase, } \\ \text { beta chain }\end{gathered}$

phosphonates ABC

lp_0715 $656135657187 \quad 1053 \quad-\quad$ phnD $\begin{array}{r}\text { transporter, substrate } \\ \text { binding protein (putative) }\end{array}$

lp_0728 $6653446669691626+$ groEL GroEL chaperonin

lp_0757 $691787692707921+$ galU UTP--glucose-1-phosphate

$\begin{array}{lllll} & & & \text { uridylyltransferase } \\ \text { endopeptidase Clp, }\end{array}$

lp_0786 $720764721354591 \quad$ - $\quad$ clpP $\quad \begin{aligned} & \text { endopeptidase Clp, } \\ & \text { proteolytic subunit }\end{aligned}$

glyceraldehyde

3-phosphate

dehydrogenase

lp_0789 $7249797260011023+$ gapB

lp_0790 7261227273241203 + pgk phosphoglycerate kinase in

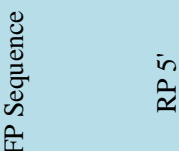

$35 \begin{gathered}\text { TAGCCACTGGTT } \\ \text { TAGCACTC }\end{gathered} 428 \begin{gathered}\text { TCAGATTCGATCG } \\ \text { TTACAGG }\end{gathered}$

$51 \begin{gathered}\text { AAAGAAACTGGG } \\ \text { CGTTAAGG }\end{gathered} 456 \begin{gathered}\text { AATCTTATCGGAA } \\ \text { ATGGCGT }\end{gathered}$

324 GCAAGCTAACAA 698 TTGTAGCCTTTCA 374 CAATACGA 698 TGTTACC TGTTGCTGGTAC 729 GTCATCGGTAACG 396 ACCATCAC ACAAGGG $123 \begin{gathered}\text { CCAAGCTCACAA } \\ \text { CACTTCAG }\end{gathered} 507 \begin{array}{cc}\text { AGCACTTGATGA } \\ \text { AGCTTGAC }\end{array} 384$

44 CTAGTCTCTTTGC 586 AACGTGAAGCAA 542 CATTGGT CATAACTG

30 ACAAGACGCATA 514 CGGCTAAGATGTC 484 CAAGAACC 514 GATACCA $212 \begin{gathered}\text { TTGTTCCAATGG } \\ \text { TTACTGAG }\end{gathered} 612 \begin{array}{cc}\text { AATACTCAGTAA } & 400 \\ \text { AGCGTCCT } & \end{array}$

196 GGTAGTTTCATTT 491 TCGTCTGTGTCAT 295 CGCTCGG 491 CAACACC

143 ACGCCCTTGATC 523 TGTAAGCATCAAC 380

$314 \begin{gathered}\text { TAAACGCCTTAT } \\ \text { TGCGTGAC }\end{gathered}$

327 CCAAGTTTCTAA 750 TGAGAAGAATGG 423

112 CTGATCGGATTA 561 ACCGATTGATAA 449

$\begin{array}{llll}49 \text { TGGATGCGTTCT } & & \text { ACCATCAG } & \\ \text { TTAGAACCAGCTT } & 457\end{array}$

71 AAGTCATCGAAC 394 TCAACCAAGCAA 323

$\begin{array}{ccc}\text { GTAGTGTC } & \text { CTTTACGG } & \\ 185 \text { ACAATTTGACGT } & \text { AAAGTTGTACGTT }\end{array}$ GGTTAGGG
GAAGTTGTACG
GGCATCC

161 TCCCTGTTGTGAT 418 CGACGGTGAATC 257 TACGGTG 418 CCATACTC $365 \begin{gathered}\text { CCCAAGTTGGTC } \\ \text { GTTTAGGT }\end{gathered} 678 \begin{array}{cc}\text { TAAATCAACACGT } \\ \text { ACCGCTG }\end{array}$

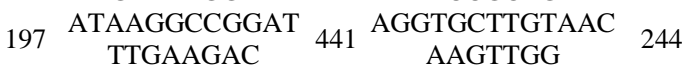

123 GTGGCATCTGTT 581 CCACTCAATAACC 458 AAGCATGG 581 GAACGAC

54 GGCAATTAACTG 489 TTGCTTCAATGGA 435 GGATCGAG 489 TCTTCGT

$27 \begin{gathered}\text { AGGTCTTTCATTC } \\ \text { ATTTCGG }\end{gathered} 399 \begin{gathered}\text { ATAAGTAGCGTCT } \\ \text { TTCAAGG }\end{gathered}$ $15 \begin{array}{ccc}\text { AAAGTTCTCTGA } \\ \text { AGATGCAC }\end{array} 397 \begin{gathered}\text { TAGCGTGTAATGA } \\ \text { GTCAACC }\end{gathered}$

153 AGACATTGTTAT 615 ACCAATGATAGC 462

22 ATtGAACAGTCA 338 AAACGCTTGCCCT 316

161 CTCATGGTACTTT 603 GAAGTTACCACC 442 GAACGCT ACGTACAG

$439 \begin{gathered}\text { GGTGATGTCTAC } \\ \text { GTCAACGA }\end{gathered} 872 \begin{gathered}\text { GAACCTTCAACA } \\ \text { ACCTTGCT }\end{gathered}$ 


\section{Continued}

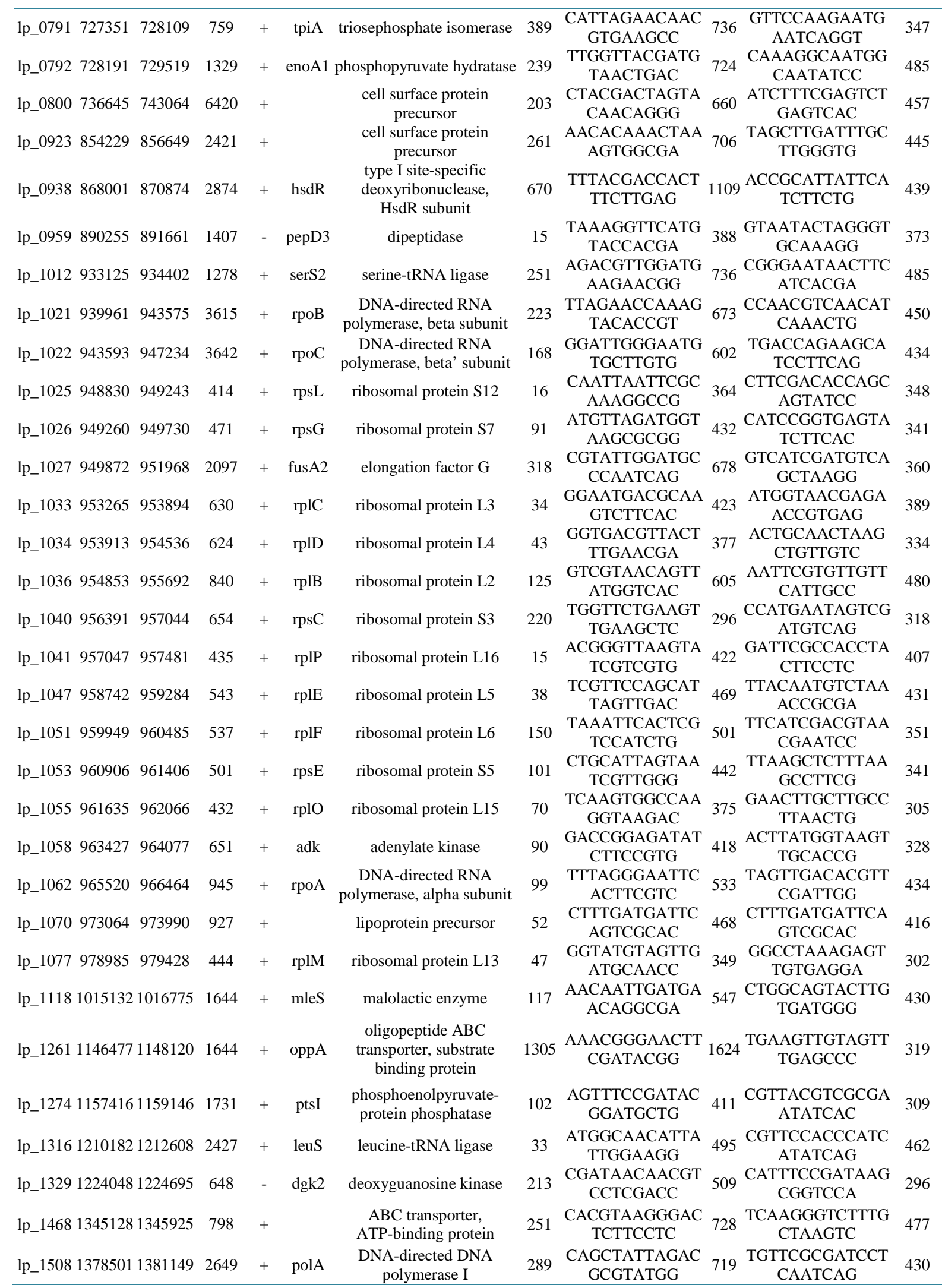




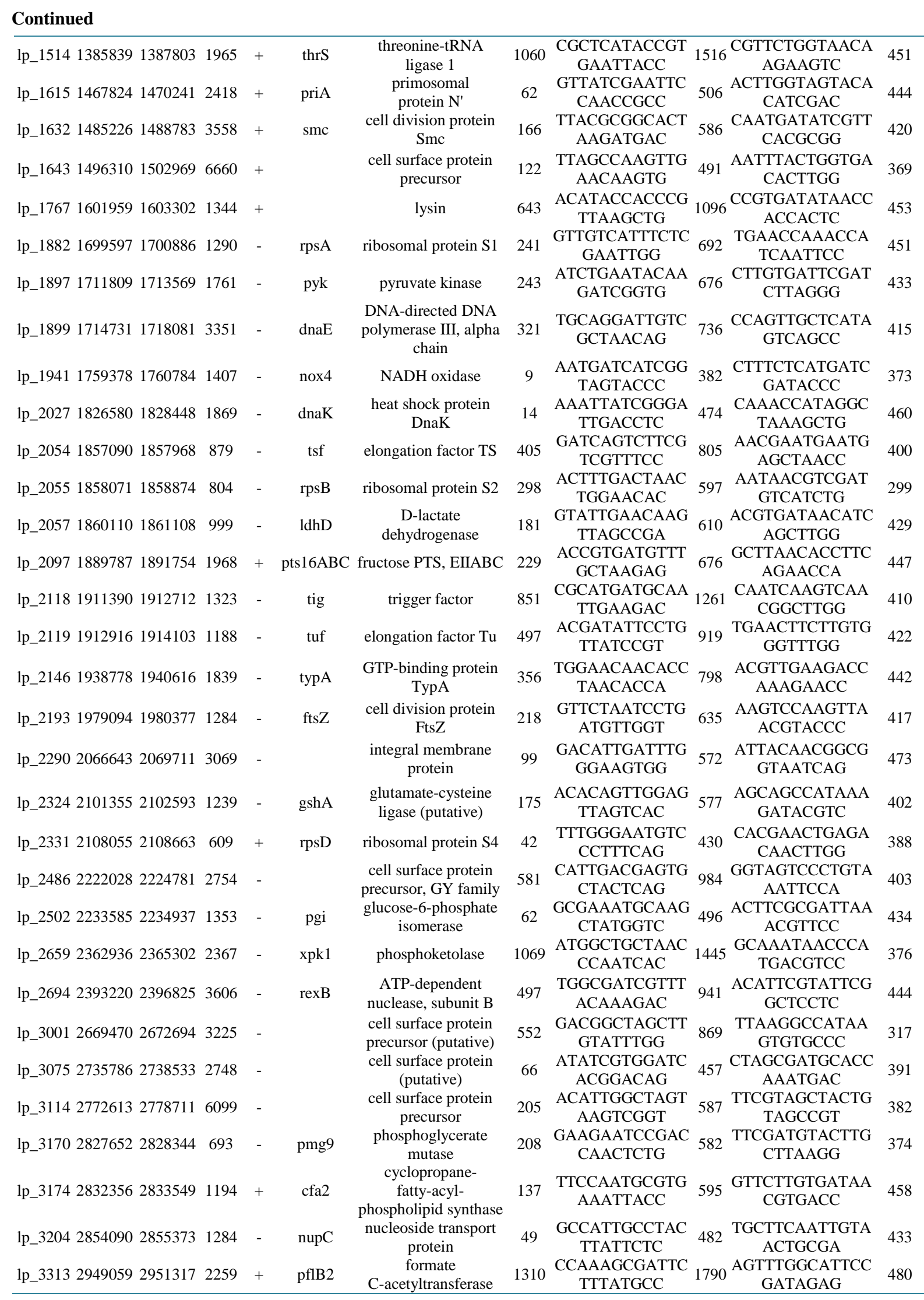




\section{Continued}

\begin{tabular}{|c|c|c|c|c|c|c|c|c|c|c|c|}
\hline \multicolumn{3}{|c|}{ lp_3421 30370103038122} & 1113 & - & & $\begin{array}{l}\text { extracellular protein, } \\
\text { gamma-D-glutamate- } \\
\text { meso-diaminopimelate } \\
\text { muropeptidase (putative) }\end{array}$ & 442 & $\begin{array}{c}\text { GCTGCTCAATCA } \\
\text { AGTAGCAC }\end{array}$ & 855 & $\begin{array}{l}\text { AGAGCAGTCCATT } \\
\text { TGTTCGT }\end{array}$ & 413 \\
\hline \multicolumn{3}{|c|}{ lp_3485 30946983096914} & 2217 & - & melA & alpha-galactosidase & 42 & $\begin{array}{l}\text { AGAACAACTTGT } \\
\text { CTTTCACC }\end{array}$ & 401 & $\begin{array}{c}\text { TCTTCGACATAAG } \\
\text { TTTGTGG }\end{array}$ & 359 \\
\hline \multicolumn{3}{|c|}{ lp_3551 31690673171478} & 2412 & + & xpk2 & phosphoketolase & 1172 & $\begin{array}{l}\text { TCGATGATTATG } \\
\text { CTTTGGAC }\end{array}$ & 1467 & $\begin{array}{l}\text { ATTGTAAGCTTCC } \\
\text { AACATCC }\end{array}$ & 295 \\
\hline \multicolumn{3}{|c|}{ lp_3662 32826113285214} & 2604 & - & adhE & $\begin{array}{l}\text { bifunctional protein: } \\
\text { alcohol dehydrogenase, } \\
\text { acetaldehyde } \\
\text { dehydrogenase }\end{array}$ & 483 & $\begin{array}{l}\text { GGAAGCGATTAA } \\
\text { AGCTGCTG }\end{array}$ & 924 & $\begin{array}{l}\text { TTTACCAGCAACT } \\
\text { GGACCAC }\end{array}$ & 441 \\
\hline \multicolumn{3}{|c|}{ lp_3665 32868163287352} & 537 & + & pdc & $\begin{array}{l}\text { p-coumaric acid } \\
\text { decarboxylase }\end{array}$ & 53 & $\begin{array}{l}\text { ACACTTATGATA } \\
\text { ACGGCTGG }\end{array}$ & 472 & $\begin{array}{c}\text { CTTTGTAAGGTGC } \\
\text { TTCACTG }\end{array}$ & 419 \\
\hline lp_0002 & 1546 & 2685 & 380 & + & dnaN & $\begin{array}{c}\text { DNA-directed DNA } \\
\text { polymerase III, beta chain }\end{array}$ & 712 & $\begin{array}{c}\text { ССТТСТАТТСТСG } \\
\text { СТТАСТС }\end{array}$ & 1129 & $\begin{array}{l}\text { CGAACTGGTGTA } \\
\text { ATCAACTG }\end{array}$ & 417 \\
\hline lp_0006 & 4565 & 6511 & 649 & + & gyrB & DNA gyrase, B subunit & 1451 & $\begin{array}{l}\text { GTTTACGGCAAT } \\
\text { GGGAACTG }\end{array}$ & 1875 & $\begin{array}{l}\text { CCATCAACATCGA } \\
\text { GAAGACC }\end{array}$ & 424 \\
\hline lp_0061 & 60505 & 61350 & 282 & + & & $\begin{array}{l}\text { acetoacetate decarboxylase } \\
\text { (putative) }\end{array}$ & 368 & $\begin{array}{l}\text { GAATGACAACAG } \\
\text { TGCGACAG }\end{array}$ & 802 & $\begin{array}{c}\text { TCATACCGACCCG } \\
\text { TTAAGAG }\end{array}$ & 434 \\
\hline lp_0129 & 114984 & 115406 & 141 & + & hsp1 & small heat shock protein & 36 & $\begin{array}{l}\text { ATGTTGGATCCG } \\
\text { TTTGAACG }\end{array}$ & 368 & $\begin{array}{l}\text { AATCGTTAAGAC } \\
\text { ACCGTCAG }\end{array}$ & 332 \\
\hline lp_0184 & 164479 & 165345 & 289 & - & sacK1 & fructokinase & 196 & $\begin{array}{c}\text { CCGATGATCCGA } \\
\text { AATATGGT }\end{array}$ & 587 & $\begin{array}{l}\text { AATATCTTTCCCA } \\
\text { GCTTTCC }\end{array}$ & 391 \\
\hline lp_0210 & 193763 & 194950 & 396 & + & ack1 & acetate kinase & 693 & $\begin{array}{l}\text { TTAACGGGTGTC } \\
\text { ACAATGGG }\end{array}$ & 1099 & $\begin{array}{l}\text { CTGATGAGTCCTT } \\
\text { CTTGACC }\end{array}$ & 406 \\
\hline lp_0233 & 213329 & 214486 & 386 & + & $\mathrm{mtlD}$ & $\begin{array}{l}\text { mannitol-1-phosphate } \\
\text { 5-dehydrogenase }\end{array}$ & 636 & $\begin{array}{c}\text { CTCTTCTCCGTTA } \\
\text { ATACTGG }\end{array}$ & 1067 & $\begin{array}{l}\text { TTGTTCGATTGGT } \\
\text { TCATCCT }\end{array}$ & 431 \\
\hline lp_0244 & 220124 & 220672 & 183 & + & & oxidoreductase (putative) & 134 & $\begin{array}{l}\text { TAACCAAGACTA } \\
\text { CGATGCGG }\end{array}$ & 498 & $\begin{array}{l}\text { CTAAGAATGATTG } \\
\text { GGTGCCT }\end{array}$ & 364 \\
\hline lp_0301 & 277394 & 278113 & 240 & - & & $\begin{array}{l}\text { membrane-bound protease, } \\
\text { CAAX family }\end{array}$ & 160 & $\begin{array}{l}\text { TAAATCGTGACT } \\
\text { GGCTACGG }\end{array}$ & 561 & $\begin{array}{l}\text { GCCATAGTAGCG } \\
\text { ATGTTGTC }\end{array}$ & 401 \\
\hline lp_0313 & 288937 & 290139 & 401 & + & ndh1 & NADH dehydrogenase & 778 & $\begin{array}{l}\text { CACACGTCATTG } \\
\text { CTGATTCC }\end{array}$ & 1179 & $\begin{array}{l}\text { CTTTACTGAAGAC } \\
\text { CGTTCCT }\end{array}$ & 401 \\
\hline lp_0329 & 300197 & 301564 & 456 & - & acdH & $\begin{array}{c}\text { acetaldehyde } \\
\text { dehydrogenase }\end{array}$ & 861 & $\begin{array}{c}\text { GAAGCAACTGTC } \\
\text { ATGAACCT }\end{array}$ & 1265 & $\begin{array}{l}\text { GAGTGTTAAGGA } \\
\text { TGGTGCGA }\end{array}$ & 404 \\
\hline lp_0466 & 417214 & 418050 & 279 & + & purR & $\begin{array}{l}\text { purine biosynthesis } \\
\text { operon repressor }\end{array}$ & 388 & $\begin{array}{l}\text { AAATCGACGCTG } \\
\text { TTATGACC }\end{array}$ & 785 & $\begin{array}{l}\text { AATCGCCTTGTCA } \\
\text { CTATCAC }\end{array}$ & 397 \\
\hline lp_0481 & 429204 & 430817 & 538 & + & pyrG & CTP synthase & 771 & $\begin{array}{c}\text { GACCAAATCGTC } \\
\text { CTTGACCA }\end{array}$ & 1214 & $\begin{array}{l}\text { TTCAGCAGAGTTA } \\
\text { GCATCCT }\end{array}$ & 443 \\
\hline lp_0566 & 522053 & 522880 & 276 & + & nadE & NAD synthase & 368 & $\begin{array}{c}\text { GGAAGCTAACCA } \\
\text { ATTGACGA }\end{array}$ & 777 & $\begin{array}{l}\text { CAGTCTTTAAGTA } \\
\text { CCACGCC }\end{array}$ & 409 \\
\hline lp_0575 & 533143 & 534117 & 325 & + & pts9AB & mannose PTS, EIIAB & 456 & $\begin{array}{l}\text { CCAGGGAAGTTG } \\
\text { GAATATGG }\end{array}$ & 811 & $\begin{array}{l}\text { TGAACTTTACCAA } \\
\text { CTGAGTG }\end{array}$ & 355 \\
\hline lp_0585 & 558254 & 561127 & 958 & + & & transcription regulator & 2308 & $\begin{array}{c}\text { TGGTCGAAATGA } \\
\text { AGACACGG }\end{array}$ & 2732 & $\begin{array}{c}\text { AATGTCTGGCATC } \\
\text { TCTTCGG }\end{array}$ & 424 \\
\hline lp_0597 & 570711 & 571388 & 226 & + & $\operatorname{pgm} 2$ & phosphoglycerate mutase & 228 & $\begin{array}{c}\text { CTGCCTGAGTAT } \\
\text { AAGACGTG }\end{array}$ & 635 & $\begin{array}{l}\text { GTGATAACAAATT } \\
\text { GGCACTC }\end{array}$ & 407 \\
\hline lp_0602 & 574097 & 574780 & 228 & - & rpiA1 & $\begin{array}{l}\text { ribose 5-phosphate } \\
\text { epimerase }\end{array}$ & 198 & $\begin{array}{l}\text { GGTATCCCGATG } \\
\text { AAATCCGT }\end{array}$ & 623 & $\begin{array}{c}\text { CATGTCTAAGAAC } \\
\text { AGGCCGT }\end{array}$ & 425 \\
\hline lp_0725 & 663325 & 664002 & 226 & + & & hypothetical protein & 198 & $\begin{array}{l}\text { GGTATCCCGATG } \\
\text { AAATCCGT }\end{array}$ & 623 & $\begin{array}{c}\text { CATGTCTAAGAAC } \\
\text { AGGCCGT }\end{array}$ & 425 \\
\hline lp_0737 & 674619 & 675185 & 189 & + & & ribosomal protein S30EA & 163 & $\begin{array}{l}\text { AAGTCACCATTC } \\
\text { CACTTCCC }\end{array}$ & 547 & $\begin{array}{c}\text { TCAATCAAACCGT } \\
\text { AACGACC }\end{array}$ & 384 \\
\hline lp_0754 & 688895 & 689842 & 316 & + & hprK & $\begin{array}{l}\text { bifunctional protein: } \mathrm{HPr} \\
\text { kinase, P-ser-HPr } \\
\text { phosphatase }\end{array}$ & 373 & $\begin{array}{l}\text { TGACGAATTACT } \\
\text { TGGAAGGT }\end{array}$ & 762 & $\begin{array}{c}\text { ATTTCCGGTTCTG } \\
\text { TTCTCCA }\end{array}$ & 389 \\
\hline lp_0807 & 748192 & 749169 & 326 & + & pta & $\begin{array}{l}\text { phosphate } \\
\text { acetyltransferase }\end{array}$ & 449 & $\begin{array}{l}\text { CTCGGGTGCATT } \\
\text { TATCATGC }\end{array}$ & 930 & $\begin{array}{c}\text { CTTCTTCACTGCA } \\
\text { TCCACGT }\end{array}$ & 481 \\
\hline lp_0852 & 790676 & 792439 & 588 & + & pox2 & pyruvate oxidase & 1360 & $\begin{array}{l}\text { GCTTGCCCGTTA } \\
\text { TTAACGTG }\end{array}$ & 1738 & $\begin{array}{l}\text { AGTAAGGCGCCT } \\
\text { AATGATGG }\end{array}$ & 378 \\
\hline lp_0853 & 792561 & 793469 & 303 & - & pepR1 & prolyl aminopeptidase & 425 & $\begin{array}{l}\text { TGTCAACGTTAA } \\
\text { CAAGTGTC }\end{array}$ & 860 & $\begin{array}{l}\text { CAAATGGTCAAA } \\
\text { GTAGACGG }\end{array}$ & 435 \\
\hline lp_1005 & 927175 & 928857 & 561 & + & als & acetolactate synthase & 1155 & $\begin{array}{c}\text { AGTGATGACATG } \\
\text { ACAGTGAC }\end{array}$ & 1562 & $\begin{array}{l}\text { ATCAGCAGGTTG } \\
\text { GTTTACCC }\end{array}$ & 407 \\
\hline lp_1090 & 992601 & 993524 & 308 & - & $\operatorname{ttd} \mathrm{A}$ & $\begin{array}{c}\mathrm{L}(+) \text {-tartrate dehydratase, } \\
\text { subunit A }\end{array}$ & 537 & $\begin{array}{l}\text { TTCGTGATGGAT } \\
\text { CGCATGAC }\end{array}$ & 914 & $\begin{array}{c}\text { TTCGACTCCTTTG } \\
\text { TTCAGTG }\end{array}$ & 377 \\
\hline
\end{tabular}




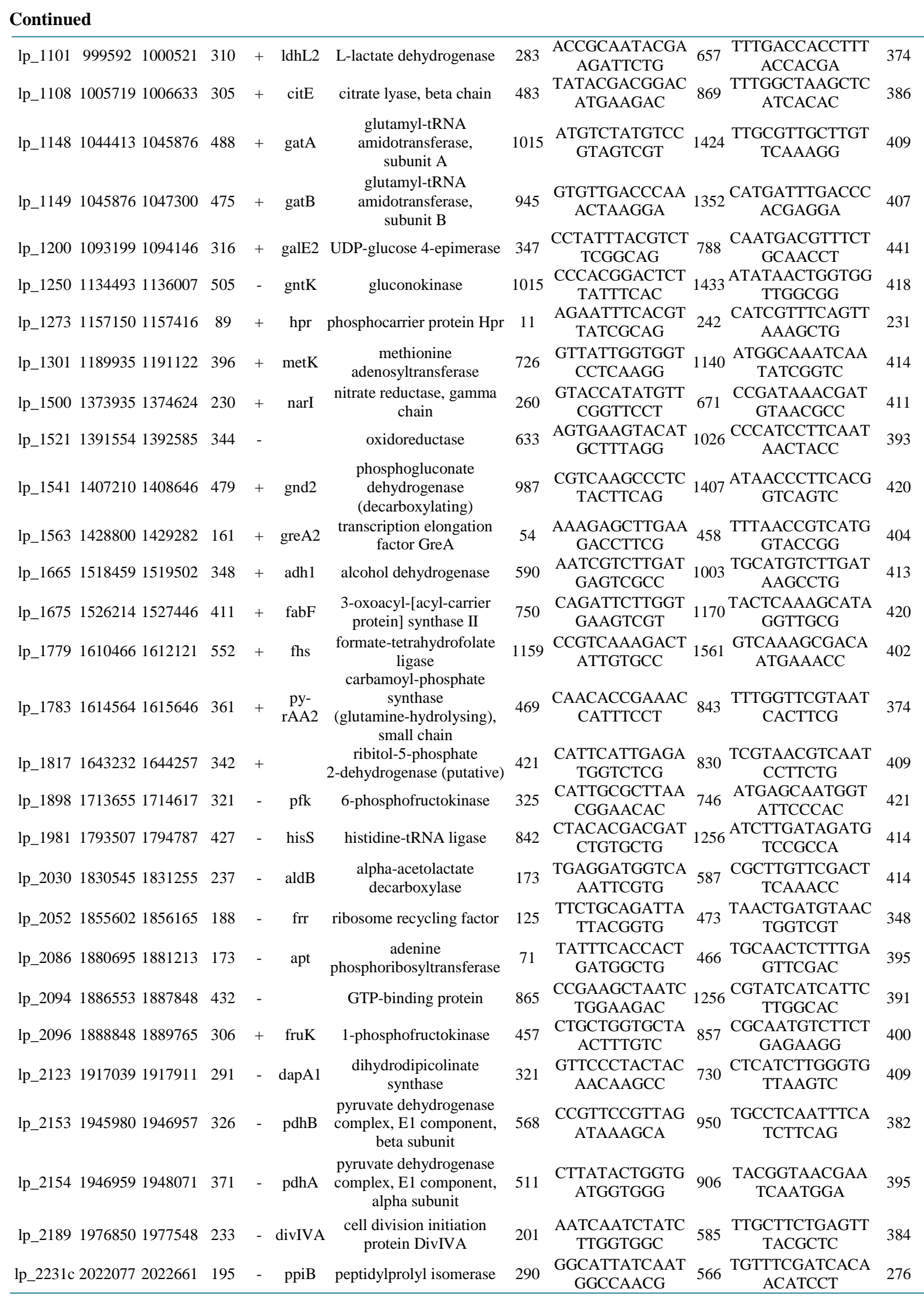




\section{Continued}

\begin{tabular}{|c|c|c|c|c|c|c|c|c|c|}
\hline lp_2256 20393142040324 & 337 & - & ссрA & catabolite control protein A & 625 & $\begin{array}{l}\text { AGGCTAAGATT } \\
\text { CCGTTTGAC }\end{array}$ & 1008 & $\begin{array}{l}\text { AATCAGCAGACTT } \\
\text { GGTTGAG }\end{array}$ & 383 \\
\hline lp_2301 20789572080099 & 381 & - & recA & recombinase $\mathrm{A}$ & 678 & $\begin{array}{l}\text { GCAGAACAGAT } \\
\text { CAAGGAAGG }\end{array}$ & 1077 & $\begin{array}{c}\text { TACTTTGACCTTT } \\
\text { ACTGCCA }\end{array}$ & 399 \\
\hline lp_2323 21006212101115 & 165 & - & tpx & thiol peroxidase & 150 & $\begin{array}{l}\text { ATGCCAGATAT } \\
\text { TGATACGCG }\end{array}$ & 463 & $\begin{array}{l}\text { GCAACGTAATTTG } \\
\text { GCTCGTG }\end{array}$ & 313 \\
\hline lp_2345 21204982121610 & 371 & - & ddl & $\begin{array}{l}\text { D-alanine-D-alanine } \\
\text { ligase }\end{array}$ & 616 & $\begin{array}{l}\text { CCGATGCGTTC } \\
\text { AAATATGAC }\end{array}$ & 1021 & $\begin{array}{l}\text { GCCGTATAACTAA } \\
\text { TGCCCGA }\end{array}$ & 405 \\
\hline lp_2349 21239352124852 & 306 & - & hicD3 & $\begin{array}{l}\text { L-2-hydroxyisocaproate } \\
\text { dehydrogenase }\end{array}$ & 467 & $\begin{array}{l}\text { AAAGTATGTCG } \\
\text { GACAAGCAG }\end{array}$ & 863 & $\begin{array}{l}\text { TAACGACGCTCGT } \\
\text { TCATCAG }\end{array}$ & 396 \\
\hline lp_2359 21301992131200 & 334 & - & mreB2 & $\begin{array}{l}\text { cell shape determining } \\
\text { protein MreB }\end{array}$ & 467 & $\begin{array}{l}\text { GACTAGTGATA } \\
\text { TCGCTGTCC }\end{array}$ & 853 & $\begin{array}{l}\text { CCACCAGTCAACG } \\
\text { TAATTCC }\end{array}$ & 386 \\
\hline lp_2366 21371182138632 & 505 & - & atpA & $\begin{array}{l}\mathrm{H}(+) \text {-transporting two-sector } \\
\text { ATPase, alpha subunit }\end{array}$ & 950 & $\begin{array}{l}\text { AATTATCGAAA } \\
\text { CGCAAGCTG }\end{array}$ & 1364 & $\begin{array}{l}\text { ACGGGCAATATCA } \\
\text { TCAACTG }\end{array}$ & 414 \\
\hline lp_2544 22695942270949 & 452 & + & npr2 & NADH peroxidase & 848 & $\begin{array}{l}\text { GACCTTAGTCC } \\
\text { CATTTGCCC }\end{array}$ & 1264 & $\begin{array}{c}\text { GCTAAGTCAGCAA } \\
\text { CAGTCAG }\end{array}$ & 416 \\
\hline lp_2596 23139482314751 & 268 & - & pflA1 & $\begin{array}{l}\text { formate acetyltransferase } \\
\text { activating enzyme }\end{array}$ & 374 & $\begin{array}{l}\text { TGAGACAACTG } \\
\text { GTTACGCAC }\end{array}$ & 793 & $\begin{array}{l}\text { TTCACCCGTACTT } \\
\text { TAACACC }\end{array}$ & 419 \\
\hline lp_2598 23158652318309 & 815 & + & pflB1 & formate C-acetyltransferase & 1991 & $\begin{array}{c}\text { AACCTCTTCTAT } \\
\text { TTCGGCCA }\end{array}$ & 2404 & $\begin{array}{c}\text { GTTTCTTTGGATA } \\
\text { GGCCCAC }\end{array}$ & 413 \\
\hline lp_2681 23804212381905 & 495 & + & gpd & $\begin{array}{l}\text { glucose-6-phosphate } \\
\text { 1-dehydrogenase }\end{array}$ & 937 & $\begin{array}{l}\text { CTTTCGTCGCTG } \\
\text { GTAAAGTC }\end{array}$ & 1355 & $\begin{array}{l}\text { AACGAATTTCCAC } \\
\text { GAATCGG }\end{array}$ & 418 \\
\hline lp_2690 23983452398983 & 213 & - & pyrE & $\begin{array}{l}\text { orotate } \\
\text { phosphoribosyltransferase }\end{array}$ & 97 & $\begin{array}{l}\text { GTATTCGCCAA } \\
\text { CCAGAACAG }\end{array}$ & 490 & $\begin{array}{l}\text { GTACCGGCATCAT } \\
\text { TGATCAG }\end{array}$ & 393 \\
\hline lp_2697 23983452398983 & 213 & - & pyrE & $\begin{array}{c}\text { orotate } \\
\text { phosphoribosyltransferase }\end{array}$ & 97 & $\begin{array}{l}\text { GTATTCGCCAA } \\
\text { CCAGAACAG }\end{array}$ & 490 & $\begin{array}{l}\text { GTACCGGCATCAT } \\
\text { TGATCAG }\end{array}$ & 393 \\
\hline lp_2699 23996952400612 & 306 & - & pyrD & dihydroorotate oxidase & 124 & $\begin{array}{c}\text { TGACGATTTCTT } \\
\text { ATCCGGCG }\end{array}$ & 527 & $\begin{array}{c}\text { GTTGGACAAACTG } \\
\text { AACAGCG }\end{array}$ & 403 \\
\hline lp_2702 24049152406207 & 431 & - & pyrC & dihydroo & 422 & $\begin{array}{l}\text { ATTTGGAACTG } \\
\text { ATCCAGCGA }\end{array}$ & 838 & $\begin{array}{l}\text { ATGTCTGTACAAG } \\
\text { CAGTCGG }\end{array}$ & 416 \\
\hline lp_2703 24062112407146 & 312 & - & pyrB & $\begin{array}{c}\text { aspartate } \\
\text { carbamoyltransferase }\end{array}$ & 869 & $\begin{array}{l}\text { GTTAGTTGCGG } \\
\text { GATTGTTGG }\end{array}$ & 1284 & $\begin{array}{c}\text { GCGTTTCCTTTCC } \\
\text { ATATGCC }\end{array}$ & 415 \\
\hline lp_2704 24072932407835 & 181 & - & pyrR1 & $\begin{array}{c}\text { pyrimidine operon } \\
\text { regulator }\end{array}$ & 554 & $\begin{array}{l}\text { CAAAGAATGGT } \\
\text { ATGGCCGTG }\end{array}$ & 932 & $\begin{array}{c}\text { AACCTCCACTTGA } \\
\text { GTTGCTG }\end{array}$ & 378 \\
\hline lp_2728 24283652429495 & 377 & - & purK1 & $\begin{array}{c}\text { phosphoribosylaminoimidazole } \\
\text { carboxylase, } \\
\text { ATPase subunit }\end{array}$ & 11 & $\begin{array}{l}\text { AGTCGTTGATG } \\
\text { CAATGACCA }\end{array}$ & 411 & $\begin{array}{l}\text { GTCCACGATCGAC } \\
\text { TAAGACC }\end{array}$ & 400 \\
\hline lp_2766 24572822458373 & 364 & + & & hypothetical protein & 680 & $\begin{array}{l}\text { AGCTAATGTTC } \\
\text { AGCCCAGTG }\end{array}$ & 1073 & $\begin{array}{c}\text { TAATACGGTGACA } \\
\text { TGACCCA }\end{array}$ & 393 \\
\hline lp_2807 25048032506059 & 419 & - & tyrS & tyrosine-tRNA ligase & 540 & $\begin{array}{l}\text { TCAAATGATGC } \\
\text { GACTTATGG }\end{array}$ & 950 & $\begin{array}{l}\text { GTATTGCCCAAAC } \\
\text { TCATCGT }\end{array}$ & 410 \\
\hline lp_2873 25582692559309 & 347 & - & adh2 & alcohol dehydrogenase & 760 & $\begin{array}{l}\text { TCAACCAGGAT } \\
\text { GATCGAGAC }\end{array}$ & 1144 & $\begin{array}{c}\text { CCATTGATTCGAA } \\
\text { TCGCACC }\end{array}$ & 384 \\
\hline lp_3051 27127412713913 & 391 & + & dhaT & $\begin{array}{l}1,3- \\
\text { deh }\end{array}$ & 440 & $\begin{array}{c}\text { AGCCTTAGCTG } \\
\text { ACGTAATGG }\end{array}$ & 856 & $\begin{array}{l}\text { CGTAAGCCAATGT } \\
\text { TCTTCCA }\end{array}$ & 416 \\
\hline lp_3092 27513342752746 & 471 & + & gabD & $\begin{array}{c}\text { succinate-semialdehyde } \\
\text { dehydrogenase (NAD(P)+) }\end{array}$ & 682 & $\begin{array}{l}\text { AAACATCATTA } \\
\text { CGCGAAGCC }\end{array}$ & 1092 & $\begin{array}{c}\text { CGTCTTTAAGCGC } \\
\text { ATTAGTC }\end{array}$ & 410 \\
\hline 7910212792502 & 494 & + & & $\begin{array}{l}\text { fumarate reductase, } \\
\text { flavoprotein subunit } \\
\text { precursor, N-terminally } \\
\text { truncated }\end{array}$ & 864 & $\begin{array}{l}\text { AAATTAGTCCC } \\
\text { TGGCGATCC }\end{array}$ & 1270 & $\begin{array}{c}\text { AGTTCTGGTAAGG } \\
\text { AGCTGAG }\end{array}$ & 406 \\
\hline lp_3265 29044442905385 & 314 & + & & $\begin{array}{l}\text { cell surface hydrolase, } \\
\text { membrane-bound } \\
\text { (putative) }\end{array}$ & 960 & $\begin{array}{l}\text { GGGAACTTCAT } \\
\text { GGGCTTAGG }\end{array}$ & 1371 & $\begin{array}{c}\text { ACGTATCACCAGT } \\
\text { TAGTCCA }\end{array}$ & 411 \\
\hline lp_3270 2910392291168 & 430 & + & purA & adenylosuccinate synthase & 474 & $\begin{array}{c}\text { CGTCACACGGA } \\
\text { TATCATCCT }\end{array}$ & 896 & $\begin{array}{c}\text { TTGATACTCGGCA } \\
\text { GGATCGA }\end{array}$ & 422 \\
\hline lp_3314 2951354295217 & 274 & + & pflA2 & $\begin{array}{l}\text { formate acetyltransferase } \\
\text { activating enzyme }\end{array}$ & 850 & $\begin{array}{c}\text { AAGTCGGTGAT } \\
\text { TTCATTCGT }\end{array}$ & 1266 & $\begin{array}{c}\text { TAACGTTAGTTTG } \\
\text { TTGGCGA }\end{array}$ & 416 \\
\hline lp_3352 29815562981999 & 148 & - & hsp3 & small heat shock protein & 398 & $\begin{array}{l}\text { GTTCGAACGTC } \\
\text { TAATGAAGG }\end{array}$ & 794 & $\begin{array}{c}\text { CTTGTACCCGTTG } \\
\text { TAATCAG }\end{array}$ & 396 \\
\hline lp_3403 3017894301875 & 287 & - & & oxidoreductase & 64 & $\begin{array}{c}\text { TGGACGATTTG } \\
\text { GTTAATGGA }\end{array}$ & 431 & $\begin{array}{c}\text { AATATGATGGGTA } \\
\text { TCCGCAG }\end{array}$ & 367 \\
\hline lp_3480 3089259309026 & 335 & - & & $\begin{array}{l}\text { UTP-galactose-1-P } \\
\text { uridylyltransferase }\end{array}$ & 321 & $\begin{array}{c}\text { GTTGACCTCTAC } \\
\text { TTGATCCA }\end{array}$ & 711 & $\begin{array}{c}\text { AGAAACCGTGTTG } \\
\text { TAATGAC }\end{array}$ & 390 \\
\hline 363930945 & 320 & + & lacM & $\begin{array}{l}\text { beta-galactosidase, small } \\
\text { subunit }\end{array}$ & 486 & $\begin{array}{c}\text { GGTCTGCGGTTT } \\
\text { ATCATACC }\end{array}$ & 882 & $\begin{array}{c}\text { AACTATCAATGCC } \\
\text { ACCGACC }\end{array}$ & 396 \\
\hline
\end{tabular}




\section{Continued}

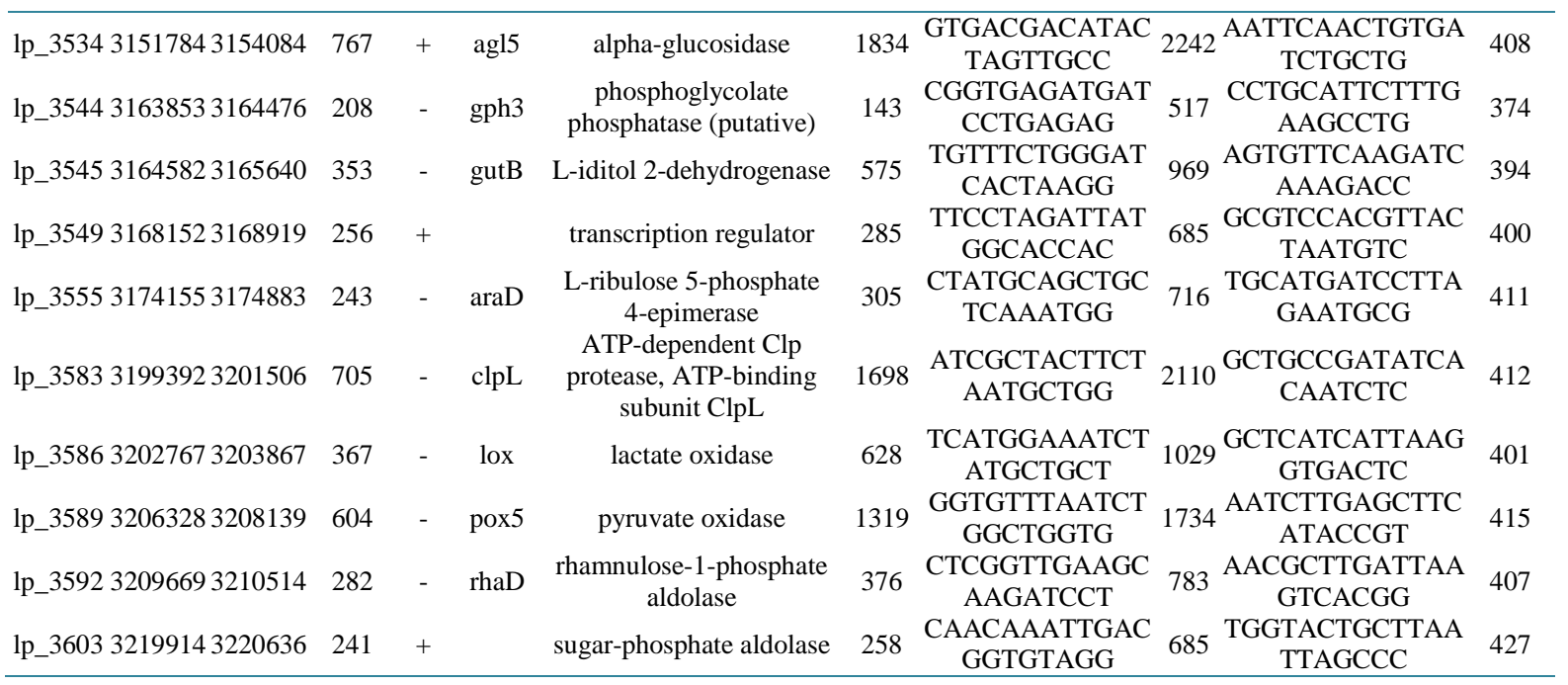

Supplement 2. Transfer of the amplified PCR products to 348 well plates for 384-pin gridding onto nitrocellulose membranes.

\begin{tabular}{|c|c|c|c|c|c|c|c|}
\hline ORF & Gene & Product & Plate_96 & 96 Well & Target Plate & 384 Well & 384 Well \\
\hline lp_0175 & malE & $\begin{array}{l}\text { maltose/maltodextrin } \mathrm{ABC} \text { transporter, substrate } \\
\text { binding protein }\end{array}$ & M2_1_96 & $\mathrm{A} 01$ & Plate_1 & A01 & A16 \\
\hline lp_0230 & pts2CB & mannitol PTS, EIICB & M2_1_96 & B01 & Plate_1 & $\mathrm{C} 01$ & C16 \\
\hline lp_0233 & mtlD & mannitol-1-phosphate 5-dehydrogenase & M2_1_96 & $\mathrm{C} 01$ & Plate_1 & E01 & E16 \\
\hline lp_0257 & рерм & methionyl aminopeptidase & M2_1_96 & D01 & Plate_1 & G01 & G16 \\
\hline lp_0302 & & extracellular protein & M2_1_96 & E01 & Plate_1 & I01 & $\mathrm{I} 16$ \\
\hline lp_0304 & & extracellular protein & M2_1_96 & F01 & Plate_1 & K01 & K16 \\
\hline lp_0330 & fba & fructose-bisphosphate aldolase & M2_1_96 & G01 & Plate_1 & M01 & M16 \\
\hline lp_0447 & mvaA & hydroxymethylglutaryl-CoA reductase & M2_1_96 & H01 & Plate_1 & $\mathrm{O} 01$ & O16 \\
\hline lp_0480 & rрoE & DNA-directed RNA polymerase, delta subunit & M2_1_96 & $\mathrm{A} 02$ & Plate_1 & A02 & A17 \\
\hline lp_0537 & ldhL1 & L-lactate dehydrogenase & M2_1_96 & B02 & Plate_1 & $\mathrm{C} 02$ & C17 \\
\hline lp_0539 & mfd & transcription-repair coupling factor & M2_1_96 & $\mathrm{C} 02$ & Plate_1 & E02 & E17 \\
\hline lp_0547 & $\mathrm{ftsH}$ & $\begin{array}{l}\text { cell division protein FtsH, ATP-dependent zinc } \\
\text { metallopeptidase }\end{array}$ & M2_1_96 & D02 & Plate_1 & G02 & G17 \\
\hline lp_0576 & pts9C & mannose PTS, EIIC & M2_1_96 & E02 & Plate_1 & I02 & $\mathrm{I} 17$ \\
\hline lp_0577 & pts9D & mannose PTS, EIID & M2_1_96 & F02 & Plate_1 & K02 & K17 \\
\hline lp_0601 & рерC1 & cysteine aminopeptidase & M2_1_96 & G02 & Plate_1 & M02 & M17 \\
\hline lp_0609 & gltX & glutamate-tRNA ligase & M2_1_96 & H02 & Plate_1 & $\mathrm{O} 02$ & $\mathrm{O} 17$ \\
\hline lp_0619 & rplK & ribosomal protein L11 & M2_1_96 & A03 & Plate_1 & A03 & A18 \\
\hline lp_0620 & rplA & ribosomal protein L1 & M2_1_96 & B03 & Plate_1 & $\mathrm{C} 03$ & C18 \\
\hline lp_0621 & rplJ & ribosomal protein L10 & M2_1_96 & $\mathrm{C} 03$ & Plate_1 & E03 & E18 \\
\hline lp_0690 & & integral membrane protein (putative) & M2_1_96 & D03 & Plate_1 & G03 & G18 \\
\hline lp_0692 & $\operatorname{nrdF}$ & ribonucleoside-diphosphate reductase, beta chain & M2_1_96 & E03 & Plate_1 & I03 & $\mathrm{I} 18$ \\
\hline lp_0715 & phnD & $\begin{array}{l}\text { phosphonates } \mathrm{ABC} \text { transporter, substrate binding } \\
\text { protein (putative) }\end{array}$ & M2_1_96 & F03 & Plate_1 & K03 & K18 \\
\hline lp_0728 & groEL & GroEL chaperonin & M2_1_96 & G03 & Plate_1 & M03 & M18 \\
\hline lp_0757 & galU & UTP-glucose-1-phosphate uridylyltransferase & M2_1_96 & H03 & Plate_1 & $\mathrm{O} 03$ & $\mathrm{O} 18$ \\
\hline lp_0786 & clpP & endopeptidase Clp, proteolytic subunit & M2_1_96 & A04 & Plate_1 & A04 & A19 \\
\hline
\end{tabular}




\section{Continued}

\begin{tabular}{|c|c|c|c|c|c|c|c|}
\hline lp_0789 & gapB & glyceraldehyde 3-phosphate dehydrogenase & M2_1_96 & B04 & Plate_1 & $\mathrm{C} 04$ & C19 \\
\hline lp_0790 & pgk & phosphoglycerate kinase & M2_1_96 & $\mathrm{C} 04$ & Plate_1 & E04 & E19 \\
\hline lp_0791 & tpiA & triosephosphate isomerase & M2_1_96 & D04 & Plate_1 & G04 & G19 \\
\hline lp_0792 & enoA1 & phosphopyruvate hydratase & M2_1_96 & E04 & Plate_1 & I04 & I19 \\
\hline lp_0800 & & cell surface protein precursor & M2_1_96 & F04 & Plate_1 & K04 & K19 \\
\hline lp_0923 & & cell surface protein precursor & M2_1_96 & G04 & Plate_1 & M04 & M19 \\
\hline lp_0938 & hsdR & type I site-specific deoxyribonuclease, HsdR subunit & M2_1_96 & $\mathrm{H} 04$ & Plate_1 & $\mathrm{O} 04$ & O19 \\
\hline lp_0959 & pepD3 & dipeptidase & M2_1_96 & A05 & Plate_1 & A05 & A20 \\
\hline lp_1012 & serS2 & serine-tRNA ligase & M2_1_96 & B05 & Plate_1 & $\mathrm{C} 05$ & C20 \\
\hline lp_1021 & rроB & DNA-directed RNA polymerase, beta subunit & M2_1_96 & $\mathrm{C} 05$ & Plate_1 & E05 & E20 \\
\hline lp_1022 & rpoC & DNA-directed RNA polymerase, beta' subunit & M2_1_96 & D05 & Plate_1 & G05 & G20 \\
\hline lp_1025 & rpsL & ribosomal protein S12 & M2_1_96 & E05 & Plate_1 & I05 & $\mathrm{I} 20$ \\
\hline lp_1026 & rpsG & ribosomal protein S7 & M2_1_96 & F05 & Plate_1 & K05 & K20 \\
\hline lp_1027 & fusA2 & elongation factor $\mathrm{G}$ & M2_1_96 & G05 & Plate_1 & M05 & M20 \\
\hline lp_1033 & rplC & ribosomal protein L3 & M2_1_96 & H05 & Plate_1 & $\mathrm{O} 05$ & $\mathrm{O} 20$ \\
\hline lp_1034 & rplD & ribosomal protein L4 & M2_1_96 & A06 & Plate_1 & A06 & A21 \\
\hline lp_1036 & rplB & ribosomal protein L2 & M2_1_96 & B06 & Plate_1 & $\mathrm{C} 06$ & $\mathrm{C} 21$ \\
\hline lp_1040 & rpsC & ribosomal protein S3 & M2_1_96 & $\mathrm{C} 06$ & Plate_1 & E06 & E21 \\
\hline lp_1041 & rplP & ribosomal protein L16 & M2_1_96 & D06 & Plate_1 & G06 & G21 \\
\hline lp_1047 & rplE & ribosomal protein L5 & M2_1_96 & E06 & Plate_1 & I06 & $\mathrm{I} 21$ \\
\hline lp_1051 & $\mathrm{rplF}$ & ribosomal protein L6 & M2_1_96 & F06 & Plate_1 & K06 & K21 \\
\hline lp_1053 & rpsE & ribosomal protein S5 & M2_1_96 & G06 & Plate_1 & M06 & M21 \\
\hline lp_1055 & rplO & ribosomal protein L15 & M2_1_96 & H06 & Plate_1 & $\mathrm{O} 06$ & $\mathrm{O} 21$ \\
\hline lp_1058 & adk & adenylate kinase & M2_1_96 & $\mathrm{A} 07$ & Plate_1 & $\mathrm{A} 07$ & A22 \\
\hline lp_1062 & гроA & DNA-directed RNA polymerase, alpha subunit & M2_1_96 & B07 & Plate_1 & $\mathrm{C} 07$ & $\mathrm{C} 22$ \\
\hline lp_1070 & & lipoprotein precursor & M2_1_96 & $\mathrm{C} 07$ & Plate_1 & E07 & E22 \\
\hline lp_1077 & rplM & ribosomal protein L13 & M2_1_96 & D07 & Plate_1 & G07 & G22 \\
\hline lp_1118 & mleS & malolactic enzyme & M2_1_96 & E07 & Plate_1 & I07 & I22 \\
\hline lp_1261 & орpA & oligopeptide $\mathrm{ABC}$ transporter, substrate binding protein & M2_1_96 & F07 & Plate_1 & K07 & K22 \\
\hline lp_1274 & ptsI & phosphoenolpyruvate-protein phosphatase & M2_1_96 & G07 & Plate_1 & M07 & M22 \\
\hline lp_1316 & leuS & leucine-tRNA ligase & M2_1_96 & H07 & Plate_1 & $\mathrm{O} 07$ & $\mathrm{O} 22$ \\
\hline lp_1329 & dgk2 & deoxyguanosine kinase & M2_1_96 & A08 & Plate_1 & A08 & A23 \\
\hline lp_1468 & & ABC transporter, ATP-binding protein & M2_1_96 & B08 & Plate_1 & $\mathrm{C} 08$ & $\mathrm{C} 23$ \\
\hline lp_1508 & polA & DNA-directed DNA polymerase I & M2_1_96 & $\mathrm{C} 08$ & Plate_1 & E08 & E23 \\
\hline lp_1514 & thrS & threonine-tRNA ligase 1 & M2_1_96 & D08 & Plate_1 & G08 & G23 \\
\hline lp_1615 & priA & primosomal protein $\mathrm{N}^{\prime}$ & M2_1_96 & E08 & Plate_1 & I08 & $\mathrm{I} 23$ \\
\hline lp_1632 & smc & cell division protein Smc & M2_1_96 & F08 & Plate_1 & K08 & K23 \\
\hline lp_1643 & & cell surface protein precursor & M2_1_96 & G08 & Plate_1 & M08 & M23 \\
\hline lp_1767 & & lysin & M2_1_96 & H08 & Plate_1 & $\mathrm{O} 08$ & $\mathrm{O} 23$ \\
\hline lp_1882 & rpsA & ribosomal protein S1 & M2_1_96 & A09 & Plate_1 & A09 & A24 \\
\hline lp_1897 & pyk & pyruvate kinase & M2_1_96 & B09 & Plate_1 & $\mathrm{C} 09$ & $\mathrm{C} 24$ \\
\hline lp_1899 & dnaE & DNA-directed DNA polymerase III, alpha chain & M2_1_96 & $\mathrm{C} 09$ & Plate_1 & E09 & E24 \\
\hline lp_1941 & nox4 & NADH oxidase & M2_1_96 & D09 & Plate_1 & G09 & G24 \\
\hline
\end{tabular}




\begin{tabular}{|c|c|c|c|c|c|c|c|}
\hline \multicolumn{8}{|c|}{ Continued } \\
\hline lp_2027 & dnaK & heat shock protein DnaK & M2_1_96 & E09 & Plate_1 & I09 & $\mathrm{I} 24$ \\
\hline lp_2054 & tsf & elongation factor TS & M2_1_96 & F09 & Plate_1 & K09 & K24 \\
\hline lp_2055 & rpsB & ribosomal protein S2 & M2_1_96 & G09 & Plate_1 & M09 & M24 \\
\hline lp_2057 & $\operatorname{ldhD}$ & D-lactate dehydrogenase & M2_1_96 & H09 & Plate_1 & O09 & $\mathrm{O} 24$ \\
\hline lp_0002 & dnaN & DNA-directed DNA polymerase III, beta chain & M2_2_96 & $\mathrm{A} 01$ & Plate_1 & B01 & B16 \\
\hline lp_0006 & gyrB & DNA gyrase, B subunit & M2_2_96 & B01 & Plate_1 & D01 & D16 \\
\hline lp_0061 & & acetoacetate decarboxylase (putative) & M2_2_96 & $\mathrm{C} 01$ & Plate_1 & F01 & F16 \\
\hline lp_0129 & hsp1 & small heat shock protein & M2_2_96 & D01 & Plate_1 & H01 & H16 \\
\hline lp_0184 & sacK1 & fructokinase & M2_2_96 & E01 & Plate_1 & J01 & J16 \\
\hline lp_0210 & ack1 & acetate kinase & M2_2_96 & F01 & Plate_1 & L01 & L16 \\
\hline lp_0233 & mtlD & mannitol-1-phosphate 5-dehydrogenase & M2_2_96 & G01 & Plate_1 & N01 & N16 \\
\hline lp_0244 & & oxidoreductase (putative) & M2_2_96 & H01 & Plate_1 & $\mathrm{P} 01$ & P16 \\
\hline lp_0301 & & membrane-bound protease, CAAX family & M2_2_96 & A02 & Plate_1 & B02 & B17 \\
\hline lp_0313 & ndh1 & NADH dehydrogenase & M2_2_96 & B02 & Plate_1 & D02 & D17 \\
\hline lp_0329 & acdH & acetaldehyde dehydrogenase & M2_2_96 & $\mathrm{C} 02$ & Plate_1 & F02 & F17 \\
\hline lp_0466 & purR & purine biosynthesis operon repressor & M2_2_96 & D02 & Plate_1 & H02 & H17 \\
\hline lp_0481 & pyrG & CTP synthase & M2_2_96 & E02 & Plate_1 & $\mathrm{J} 02$ & $\mathrm{~J} 17$ \\
\hline lp_0566 & nadE & NAD synthase & M2_2_96 & F02 & Plate_1 & L02 & L17 \\
\hline lp_0575 & pts9AB & mannose PTS, EIIAB & M2_2_96 & G02 & Plate_1 & N02 & N17 \\
\hline lp_0585 & & transcription regulator & M2_2_96 & H02 & Plate_1 & P02 & P17 \\
\hline lp_0597 & pgm2 & phosphoglycerate mutase & M2_2_96 & A03 & Plate_1 & B03 & B18 \\
\hline lp_0602 & rpiA1 & ribose 5-phosphate epimerase & M2_2_96 & B03 & Plate_1 & D03 & D18 \\
\hline lp_0725 & & hypothetical protein & M2_2_96 & $\mathrm{C} 03$ & Plate_1 & F03 & F18 \\
\hline lp_0737 & & ribosomal protein S30EA & M2_2_96 & D03 & Plate_1 & H03 & H18 \\
\hline lp_0754 & hprK & bifunctional protein: HPr kinase, P-ser-HPr phosphatase & M2_2_96 & E03 & Plate_1 & J03 & J18 \\
\hline lp_0807 & pta & phosphate acetyltransferase & M2_2_96 & F03 & Plate_1 & L03 & L18 \\
\hline lp_0852 & pox2 & pyruvate oxidase & M2_2_96 & G03 & Plate_1 & N03 & N18 \\
\hline lp_0853 & pepR1 & prolyl aminopeptidase & M2_2_96 & H03 & Plate_1 & P03 & P18 \\
\hline lp_1005 & als & acetolactate synthase & M2_2_96 & A04 & Plate_1 & B04 & B19 \\
\hline lp_1090 & $\operatorname{ttd} A$ & $\mathrm{~L}(+)$-tartrate dehydratase, subunit A & M2_2_96 & B04 & Plate_1 & D04 & D19 \\
\hline lp_1101 & ldhL2 & L-lactate dehydrogenase & M2_2_96 & $\mathrm{C} 04$ & Plate_1 & F04 & F19 \\
\hline lp_1108 & citE & citrate lyase, beta chain & M2_2_96 & D04 & Plate_1 & H04 & H19 \\
\hline lp_1148 & gat $\mathrm{A}$ & glutamyl-tRNA amidotransferase, subunit A & M2_2_96 & E04 & Plate_1 & J04 & J19 \\
\hline lp_1149 & gatB & glutamyl-tRNA amidotransferase, subunit B & M2_2_96 & F04 & Plate_1 & L04 & L19 \\
\hline lp_1200 & galE2 & UDP-glucose 4-epimerase & M2_2_96 & G04 & Plate_1 & N04 & N19 \\
\hline lp_1250 & gntK & gluconokinase & M2_2_96 & H04 & Plate_1 & P04 & P19 \\
\hline lp_1273 & hpr & phosphocarrier protein Hpr & M2_2_96 & A05 & Plate_1 & B05 & $\mathrm{B} 20$ \\
\hline lp_1301 & metK & methionine adenosyltransferase & M2_2_96 & B05 & Plate_1 & D05 & D20 \\
\hline lp_1500 & narI & nitrate reductase, gamma chain & M2_2_96 & $\mathrm{C} 05$ & Plate_1 & F05 & F20 \\
\hline lp_1521 & & oxidoreductase & M2_2_96 & D05 & Plate_1 & H05 & H20 \\
\hline lp_1541 & gnd2 & phosphogluconate dehydrogenase (decarboxylating) & M2_2_96 & E05 & Plate_1 & $\mathrm{J} 05$ & $\mathrm{~J} 20$ \\
\hline lp_1563 & greA2 & transcription elongation factor GreA & M2_2_96 & F05 & Plate_1 & L05 & L20 \\
\hline lp_1665 & adh1 & alcohol dehydrogenase & M2_2_96 & G05 & Plate_1 & N05 & N20 \\
\hline
\end{tabular}




\section{Continued}

\begin{tabular}{|c|c|c|c|c|c|c|c|}
\hline lp_1675 & fabF & 3-oxoacyl-[acyl-carrier protein] synthase II & M2_2_96 & H05 & Plate_1 & P05 & P20 \\
\hline lp_1779 & fhs & formate-tetrahydrofolate ligase & M2_2_96 & A06 & Plate_1 & B06 & B21 \\
\hline lp_1783 & pyrAA2 & $\begin{array}{l}\text { carbamoyl-phosphate synthase } \\
\text { (glutamine-hydrolysing), small chain }\end{array}$ & M2_2_96 & B06 & Plate_1 & D06 & D21 \\
\hline lp_1817 & & ribitol-5-phosphate 2-dehydrogenase (putative) & M2_2_96 & $\mathrm{C} 06$ & Plate_1 & F06 & F21 \\
\hline lp_1898 & $\mathrm{pfk}$ & 6-phosphofructokinase & M2_2_96 & D06 & Plate_1 & H06 & H21 \\
\hline lp_1981 & hisS & histidine-tRNA ligase & M2_2_96 & E06 & Plate_1 & J06 & $\mathrm{J} 21$ \\
\hline lp_2030 & aldB & alpha-acetolactate decarboxylase & M2_2_96 & F06 & Plate_1 & L06 & L21 \\
\hline lp_2052 & frr & ribosome recycling factor & M2_2_96 & G06 & Plate_1 & N06 & N21 \\
\hline lp_2086 & apt & adenine phosphoribosyltransferase & M2_2_96 & H06 & Plate_1 & P06 & P21 \\
\hline lp_2094 & & GTP-binding protein & M2_2_96 & $\mathrm{A} 07$ & Plate_1 & B07 & B22 \\
\hline lp_2096 & fruK & 1-phosphofructokinase & M2_2_96 & B07 & Plate_1 & D07 & D22 \\
\hline lp_2123 & dapA1 & dihydrodipicolinate synthase & M2_2_96 & $\mathrm{C} 07$ & Plate_1 & F07 & F22 \\
\hline lp_2153 & pdhB & $\begin{array}{l}\text { pyruvate dehydrogenase complex, E1 component, } \\
\text { beta subunit }\end{array}$ & M2_2_96 & D07 & Plate_1 & $\mathrm{H} 07$ & $\mathrm{H} 22$ \\
\hline lp_2154 & pdhA & $\begin{array}{l}\text { pyruvate dehydrogenase complex, E1 component, } \\
\text { alpha subunit }\end{array}$ & M2_2_96 & E07 & Plate_1 & J07 & $\mathrm{J} 22$ \\
\hline lp_2189 & $\operatorname{divIVA}$ & cell division initiation protein DivIVA & M2_2_96 & F07 & Plate_1 & L07 & L22 \\
\hline lp_2231c & ppiB & peptidylprolyl isomerase & M2_2_96 & G07 & Plate_1 & N07 & N22 \\
\hline lp_2256 & ссрA & catabolite control protein A & M2_2_96 & H07 & Plate_1 & P07 & P22 \\
\hline lp_2301 & recA & recombinase $\mathrm{A}$ & M2_2_96 & A08 & Plate_1 & B08 & B23 \\
\hline lp_2323 & tpx & thiol peroxidase & M2_2_96 & B08 & Plate_1 & D08 & D23 \\
\hline lp_2345 & ddl & D-alanine-D-alanine ligase & M2_2_96 & $\mathrm{C} 08$ & Plate_1 & F08 & F23 \\
\hline lp_2349 & hicD3 & L-2-hydroxyisocaproate dehydrogenase & M2_2_96 & D08 & Plate_1 & H08 & $\mathrm{H} 23$ \\
\hline lp_2359 & mreB2 & cell shape determining protein MreB & M2_2_96 & E08 & Plate_1 & $\mathrm{J} 08$ & $\mathrm{~J} 23$ \\
\hline lp_2366 & atpA & $\mathrm{H}(+)$-transporting two-sector ATPase, alpha subunit & M2_2_96 & F08 & Plate_1 & L08 & L23 \\
\hline lp_2544 & npr2 & NADH peroxidase & M2_2_96 & G08 & Plate_1 & N08 & N23 \\
\hline lp_2596 & pflA1 & formate acetyltransferase activating enzyme & M2_2_96 & H08 & Plate_1 & P08 & P23 \\
\hline lp_2598 & pflB1 & formate C-acetyltransferase & M2_2_96 & A09 & Plate_1 & B09 & B24 \\
\hline lp_2681 & gpd & glucose-6-phosphate 1-dehydrogenase & M2_2_96 & B09 & Plate_1 & D09 & D24 \\
\hline lp_2690 & pyrE & orotate phosphoribosyltransferase & M2_2_96 & $\mathrm{C} 09$ & Plate_1 & F09 & F24 \\
\hline lp_2697 & pyrD & dihydroorotate oxidase & M2_2_96 & D09 & Plate_1 & H09 & $\mathrm{H} 24$ \\
\hline lp_2699 & pyrC & dihydroorotase & M2_2_96 & E09 & Plate_1 & J09 & $\mathrm{J} 24$ \\
\hline lp_2702 & pyrB & aspartate carbamoyltransferase & M2_2_96 & F09 & Plate_1 & L09 & L24 \\
\hline lp_2703 & pyrR1 & pyrimidine operon regulator & M2_2_96 & G09 & Plate_1 & N09 & N24 \\
\hline lp_2704 & purK1 & $\begin{array}{l}\text { phosphoribosylaminoimidazole carboxylase, ATPase } \\
\text { subunit }\end{array}$ & M2_2_96 & H09 & Plate_1 & P09 & P24 \\
\hline lp_2097 & pts16ABC & fructose PTS, EIIABC & M2_1_96 & A10 & Plate_2 & A01 & A22 \\
\hline lp_2118 & tig & trigger factor & M2_1_96 & B10 & Plate_2 & $\mathrm{C} 01$ & $\mathrm{C} 22$ \\
\hline lp_2119 & tuf & elongation factor $\mathrm{Tu}$ & M2_1_96 & $\mathrm{C} 10$ & Plate_2 & E01 & E22 \\
\hline lp_2146 & typA & GTP-binding protein TypA & M2_1_96 & D10 & Plate_2 & G01 & G22 \\
\hline lp_2193 & ftsZ & cell division protein FtsZ & M2_1_96 & E10 & Plate_2 & $\mathrm{I} 01$ & $\mathrm{I} 22$ \\
\hline lp_2290 & & integral membrane protein & M2_1_96 & F10 & Plate_2 & K01 & K22 \\
\hline lp_2324 & gshA & glutamate-cysteine ligase (putative) & M2_1_96 & G10 & Plate_2 & M01 & M22 \\
\hline lp_2331 & rpsD & ribosomal protein S4 & M2_1_96 & $\mathrm{H} 10$ & Plate_2 & $\mathrm{O} 01$ & $\mathrm{O} 22$ \\
\hline lp_2486 & & cell surface protein precursor, GY family & M2_1_96 & A11 & Plate_2 & A02 & A23 \\
\hline
\end{tabular}




\begin{tabular}{|c|c|c|c|c|c|c|c|}
\hline \multicolumn{8}{|c|}{ Continued } \\
\hline lp_2502 & pgi & glucose-6-phosphate isomerase & M2_1_96 & B11 & Plate_2 & $\mathrm{C} 02$ & $\mathrm{C} 23$ \\
\hline lp_2659 & xpk1 & phosphoketolase & M2_1_96 & $\mathrm{C} 11$ & Plate_2 & E02 & E23 \\
\hline lp_2694 & rexB & ATP-dependent nuclease, subunit B & M2_1_96 & D11 & Plate_2 & G02 & G23 \\
\hline lp_3001 & & cell surface protein precursor (putative) & M2_1_96 & E11 & Plate_2 & I02 & $\mathrm{I} 23$ \\
\hline lp_3075 & & cell surface protein (putative) & M2_1_96 & F11 & Plate_2 & K02 & K23 \\
\hline lp_3114 & & cell surface protein precursor & M2_1_96 & G11 & Plate_2 & M02 & M23 \\
\hline lp_3170 & pmg9 & phosphoglycerate mutase & M2_1_96 & H11 & Plate_2 & $\mathrm{O} 02$ & $\mathrm{O} 23$ \\
\hline lp_3174 & $\mathrm{cfa} 2$ & cyclopropane-fatty-acyl-phospholipid synthase & M2_1_96 & A12 & Plate_2 & A03 & A24 \\
\hline lp_3204 & nupC & nucleoside transport protein & M2_1_96 & B12 & Plate_2 & $\mathrm{C} 03$ & $\mathrm{C} 24$ \\
\hline lp_3313 & pflB2 & formate C-acetyltransferase & M2_1_96 & $\mathrm{C} 12$ & Plate_2 & E03 & E24 \\
\hline lp_3421 & & $\begin{array}{l}\text { extracellular protein, gamma-D-glutamate- } \\
\text { meso-diaminopimelate muropeptidase (putative) }\end{array}$ & M2_1_96 & D12 & Plate_2 & G03 & G24 \\
\hline lp_3485 & melA & alpha-galactosidase & M2_1_96 & E12 & Plate_2 & I03 & $\mathrm{I} 24$ \\
\hline lp_3551 & xpk2 & phosphoketolase & M2_1_96 & F12 & Plate_2 & K03 & K24 \\
\hline lp_3662 & adhE & $\begin{array}{l}\text { bifunctional protein: alcohol dehydrogenase, } \\
\text { acetaldehyde dehydrogenase }\end{array}$ & M2_1_96 & G12 & Plate_2 & M03 & M24 \\
\hline lp_3665 & pdc & p-coumaric acid decarboxylase & M2_1_96 & H12 & Plate_2 & $\mathrm{O} 03$ & $\mathrm{O} 24$ \\
\hline lp_2728 & & hypothetical protein & M2_2_96 & A10 & Plate_2 & B01 & B22 \\
\hline lp_2766 & tyrS & tyrosine-tRNA ligase & M2_2_96 & B10 & Plate_2 & D01 & D22 \\
\hline lp_2807 & adh2 & alcohol dehydrogenase & M2_2_96 & $\mathrm{C} 10$ & Plate_2 & F01 & F22 \\
\hline lp_2873 & dhaT & 1,3-propanediol dehydrogenase & M2_2_96 & D10 & Plate_2 & H01 & H22 \\
\hline lp_3051 & gabD & succinate-semialdehyde dehydrogenase $(\mathrm{NAD}(\mathrm{P})+)$ & M2_2_96 & E10 & Plate_2 & $\mathrm{J} 01$ & $\mathrm{~J} 22$ \\
\hline lp_3092 & & $\begin{array}{l}\text { fumarate reductase, flavoprotein subunit precursor, } \\
\text { N-terminally truncated }\end{array}$ & M2_2_96 & F10 & Plate_2 & L01 & L22 \\
\hline lp_3125 & & cell surface hydrolase, membrane-bound (putative) & M2_2_96 & G10 & Plate_2 & N01 & N22 \\
\hline lp_3265 & purA & adenylosuccinate synthase & M2_2_96 & H10 & Plate_2 & P01 & P22 \\
\hline lp_3270 & pflA2 & formate acetyltransferase activating enzyme & M2_2_96 & A11 & Plate_2 & B02 & B23 \\
\hline lp_3314 & hsp3 & small heat shock protein & M2_2_96 & B11 & Plate_2 & D02 & D23 \\
\hline lp_3352 & & oxidoreductase & M2_2_96 & $\mathrm{C} 11$ & Plate_2 & F02 & F23 \\
\hline lp_3403 & galE4 & UDP-glucose 4-epimerase & M2_2_96 & D11 & Plate_2 & H02 & $\mathrm{H} 23$ \\
\hline lp_3482 & galK & galactokinase & M2_2_96 & E11 & Plate_2 & J02 & $\mathrm{J} 23$ \\
\hline lp_3484 & lacM & beta-galactosidase, small subunit & M2_2_96 & F11 & Plate_2 & L02 & L23 \\
\hline lp_3534 & agl5 & alpha-glucosidase & M2_2_96 & G11 & Plate_2 & N02 & N23 \\
\hline lp_3544 & gph3 & phosphoglycolate phosphatase (putative) & M2_2_96 & H11 & Plate_2 & P02 & $\mathrm{P} 23$ \\
\hline lp_3545 & gutB & L-iditol 2-dehydrogenase & M2_2_96 & A12 & Plate_2 & В03 & B24 \\
\hline lp_3549 & & transcription regulator & M2_2_96 & B12 & Plate_2 & D03 & D24 \\
\hline lp_3555 & araD & L-ribulose 5-phosphate 4-epimerase & M2_2_96 & $\mathrm{C} 12$ & Plate_2 & F03 & F24 \\
\hline lp_3583 & clpL & $\begin{array}{l}\text { ATP-dependent Clp protease, ATP-binding subunit } \\
\text { ClpL }\end{array}$ & M2_2_96 & D12 & Plate_2 & H03 & $\mathrm{H} 24$ \\
\hline lp_3586 & lox & lactate oxidase & M2_2_96 & E12 & Plate_2 & J03 & $\mathrm{J} 24$ \\
\hline lp_3589 & pox5 & pyruvate oxidase & M2_2_96 & F12 & Plate_2 & L03 & L24 \\
\hline lp_3592 & rhaD & rhamnulose-1-phosphate aldolase & M2_2_96 & G12 & Plate_2 & N03 & N24 \\
\hline lp_3603 & & sugar-phosphate aldolase & M2_2_96 & H12 & Plate_2 & P03 & $\mathrm{P} 24$ \\
\hline
\end{tabular}


Scientific Research Publishing (SCIRP) is one of the largest Open Access journal publishers. It is currently publishing more than 200 open access, online, peer-reviewed journals covering a wide range of academic disciplines. SCIRP serves the worldwide academic communities and contributes to the progress and application of science with its publication.

Other selected journals from SCIRP are listed as below. Submit your manuscript to us via either submit@scirp.org or Online Submission Portal.
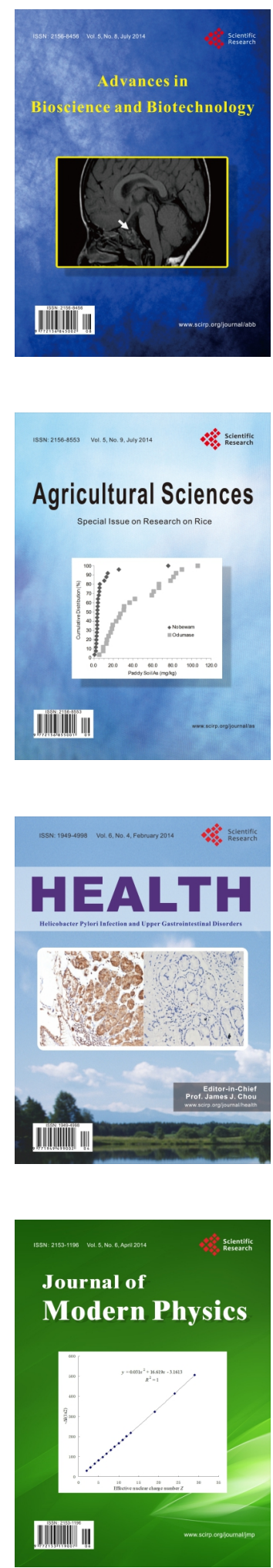
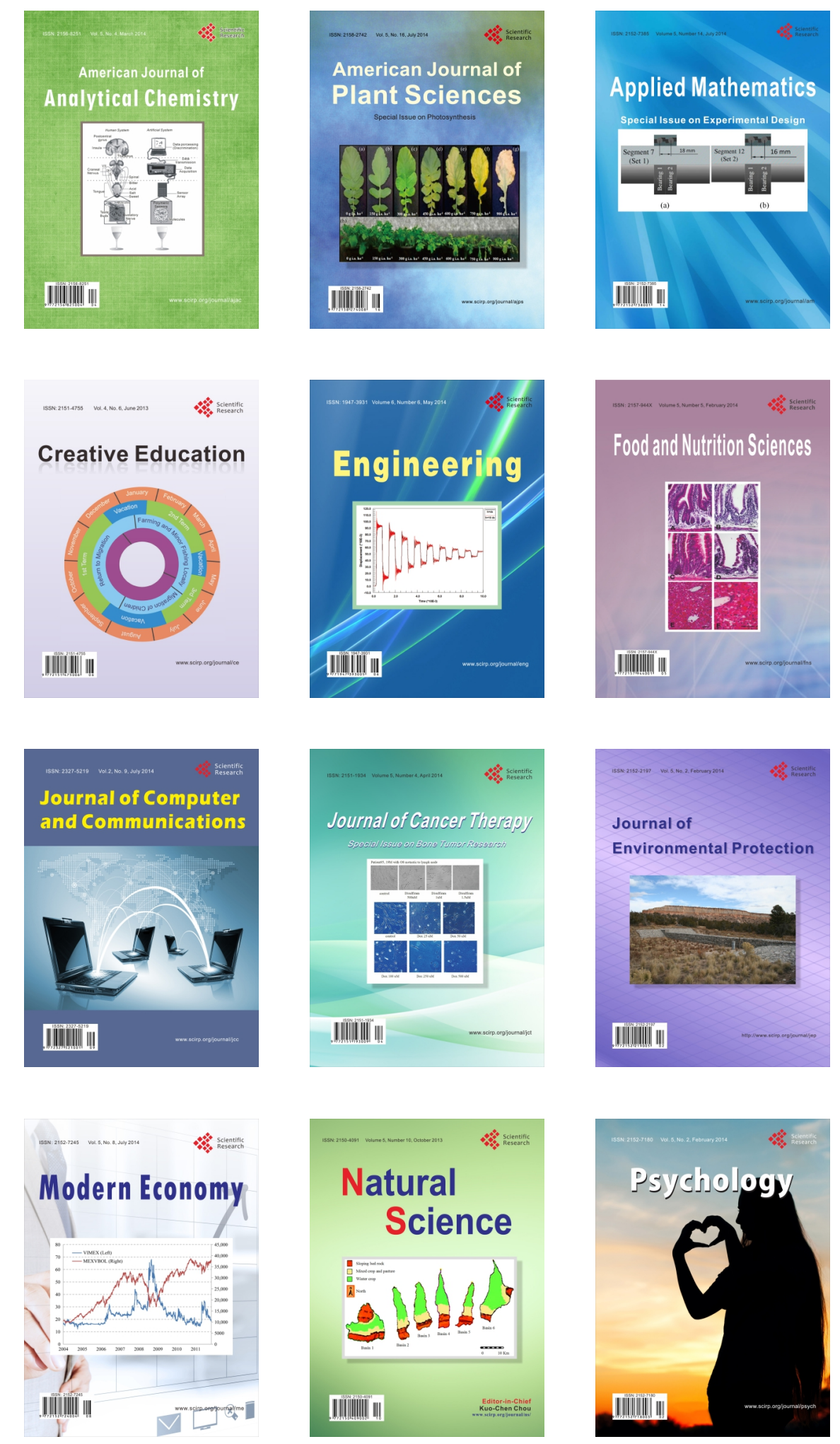